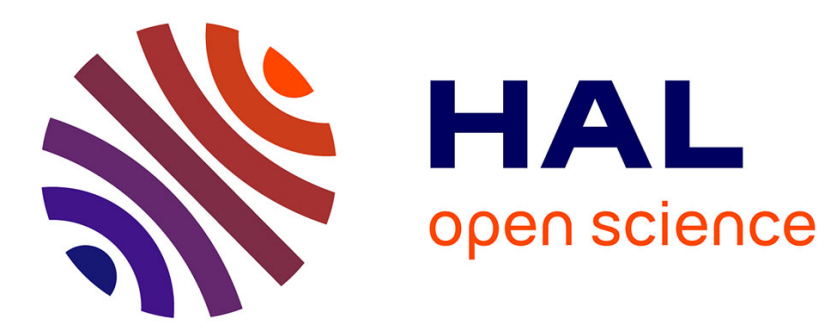

\title{
Nonchemical pest control in China rice: a review
}

Shiwen Huang, Ling Wang, Lianmeng Liu, Qian Fu, Defeng Zhu

\section{To cite this version:}

Shiwen Huang, Ling Wang, Lianmeng Liu, Qian Fu, Defeng Zhu. Nonchemical pest control in China rice: a review. Agronomy for Sustainable Development, 2014, 34 (2), pp.275-291. 10.1007/s13593013-0199-9 . hal-01234819

\section{HAL Id: hal-01234819 https://hal.science/hal-01234819}

Submitted on 27 Nov 2015

HAL is a multi-disciplinary open access archive for the deposit and dissemination of scientific research documents, whether they are published or not. The documents may come from teaching and research institutions in France or abroad, or from public or private research centers.
L'archive ouverte pluridisciplinaire HAL, est destinée au dépôt et à la diffusion de documents scientifiques de niveau recherche, publiés ou non, émanant des établissements d'enseignement et de recherche français ou étrangers, des laboratoires publics ou privés. 


\section{Nonchemical pest control in China rice: a review}

\author{
Shiwen Huang • Ling Wang • Lianmeng Liu • Qian Fu • \\ Defeng Zhu
}

Accepted: 14 November 2013 /Published online: 18 December 2013

(C) INRA and Springer-Verlag France 2013

\begin{abstract}
Major pests such as blast, sheath blight, bacterial blight, plant hoppers, leaf folder, and stem borers occur in rice paddy fields. These pests cause high damage to the grain and straw yield. The application of high $\mathrm{N}$ fertilizer loads increases the predisposition of rice crops to be infected by pests. Many agrochemicals used to control pests lead to pest adaptation and resistance, loss of soil fertility and organic carbon, soil erosion, decreasing biodiversity, and desertification. Chemical fertilizers and pesticides unduly applied also lead to major impact on environment and food safety. Here, we review nonchemicals control methods such as genomic diversity of rice host; cultural practices; physical measures; duck, fish, and bullfrog with rice commensalism; and biogas fermentative liquid and residue. We also discuss the current progress of nonchemical control methods in China.
\end{abstract}

Keywords Rice $\cdot$ Rice major pests $\cdot$ Pests management · Nonchemical approaches

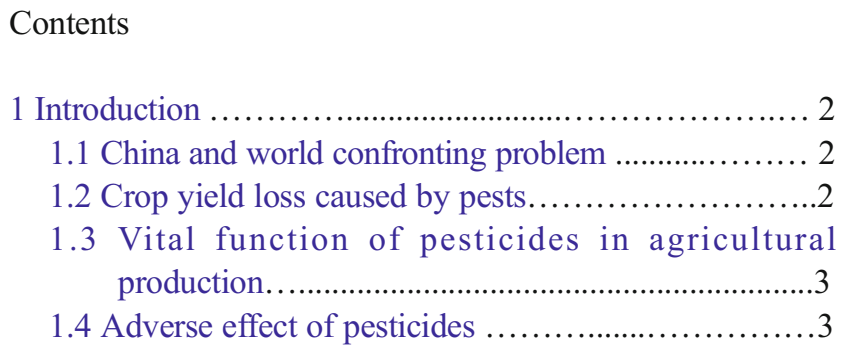

S. Huang $\cdot$ L. Wang $\cdot$ L. Liu $\cdot$ Q. Fu $\cdot$ D. Zhu

China National Rice Research Institute, Hangzhou 310006, People's Republic of China

S. Huang $(\bowtie) \cdot$ L. Wang $\cdot$ L. Liu $\cdot$ Q. Fu $\cdot$ D. Zhu

No. 28 Shui Dao Suo Road, Fuyang City, Hangzhou Zhejiang

Province, People's Republic of China 311401

e-mail: hswswh666@126.com
1.5 Resolve measures of side effect caused by pesticides.

4

2 Rice pests management by mixed growth of different resistance rice varieties.......................................... 5

2.1 Disease management through genetic diversity.......... 5

2.2 Control efficiency of plant hoppers by inheritance diversity..............................................6

2.3 Effects of mixture planting on rice yield...............6

3 Adjusting rice seeding and transplanting date to reduce pest injuries.........................................................

3.1 Effect of seeding and transplanting date on insect pests.........................................................

3.2 Effect of seeding and transplanting date on sheath blight.

4 Releasing fish and frog in rice paddy field to control

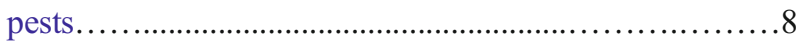

5 Rearing duck in paddy field to control pests............... 9

6 Seeds soaking with biogas fermentative liquid and seedling cultivation with biogas fermentative residues.............10

6.1 Seeds soaked with biogas liquid......................10

6.2 Rice seedling cultivation with biogas residues.........10

7 Rice Insect Pests Control by Jiaduo Frequoscillation Pestkilling Lamp ............................................11

7.1 Installation of pest-killing lamp and control distance range...

7.2 Control efficiency of pest-killing lamp to different insect pests

(1) Control effect on rice leaf folder (Chaphalocrocis medina ) .... .12

(2) Control effect on rice stem borers..............12

(3) Control efficiency to plant hoppers..............12

7.3 Effect of pest-killing lamp on natural enemies.......13

7.4 Effects of pest-killing lamp on on rice yield............13

7.5 Benefit analysis of pest-killing lamp.........................13

Acknowledgements.......................................... 14

References......................................................... 


\section{Introduction}

\subsection{China and world confronting problem}

The seven billion global populations are projected to grow by 70 million per annum, increasing by $30 \%$ to 9.2 billion by 2050. This increased population density is projected to increase demand for food production by $70 \%$ notably due to changes in dietary habits in developing countries towards high quality food, e.g., greater consumption of meat and milk products and to the increasing use of grains for livestock feed (Popp et al. 2013). Global food production must increase by $50 \%$ to meet the projected demand of the world's population by 2050 (Chakraborty et al. 2011). Thus, we need to grow food on even less land, with less water, using less energy, fertilizer, and pesticide than we use today (Popp et al. 2013).

China is the biggest developing country with the population of more than 13.47 billion (2011) and still increasing its population at the natural growth rate of $4.79 \%$ annually (2011) (the population of China statistical table, 2012) that signify 6.45 million persons added each year. China is facing one of the largest challenges of this century to continue to increase annual cereal production to about 600 million tons by 2030 to ensure food security with shrinking agro-land and limited resources, while maintaining or improving soil fertility, and protecting the environment (Miao et al. 2011).

Rice production possesses vital position in China. China now is the biggest country of rice production and consumption in world. In China, the total rice sown area was 29,873 thousand hectares and the total output was 195.76 million tons in 2010, the total rice output of China account for about $35 \%$ of the world rice total output. There are $65 \%$ of Chinese people that (about 0.87 billion) feed on rice as their staple food. The measure of consumption of rice was 186.50 million tons in 2010 account for $94.7 \%$ of rice total output in China; thereinto, 156.25 million tons were consumed as grain ration, account for $83.8 \%$ of rice measure of consumption, and account for $33.7 \%$ of the measure of consumption of grain (China National Rice Research Institute (CNRRI) 2011).

\subsection{Crop yield loss caused by pests}

Crop productivity may be increased in many regions by highyielding varieties, improved water and soil management, fertilization, and other cultivation techniques. An increased yield potential of crops, however, is often associated with higher vulnerability to pests attack leading to increasing absolute losses and loss rates (Oerke et al. 1994). An important constraint to achieving higher rice yield is losses caused by pests. Pests are organisms that attack the rice crop or compete with it for nutrients, causing yield reductions. The common organism pests of rice are insects, weeds, molluscs, mammals, birds, fungal and bacterial pathogens, and viruses.
The annual global chemical-pesticide market is about 3 million tons associated with expenditures around USD 40 billion (Popp 2011). The studies estimate that aggregate crop losses amounted to $37 \%$ of total output in 1986, up from $33 \%$ in 1974 (Pimentel 1993).

The reduction of current yield losses caused by insect pests, diseases caused by pathogens, and weeds are major challenges to agricultural production (Oerke and Dehne 2004), globally, an average of $35 \%$ of potential crop yield is lost to preharvest pests (Oerke 2005).

Since crop production technology and especially crop protection methods are changing continuously, loss data for eight major food and cash crops - wheat, rice, maize, barley, potatoes, soybeans, sugar beet, and cotton - have been updated for the period 1996-1998 on a regional basis for 17 regions (Oerke and Dehne 2004). Among crops, the loss potential of pests worldwide varied from less than $50 \%$ (on barley) to more than $80 \%$ (on sugar beet and cotton). Actual losses were estimated at 26-30\% for sugar beet, barley, soybean, wheat, and cotton, and 35,39 , and $40 \%$ for maize, potatoes, and rice, respectively (Oerke and Dehne 2004).

\subsection{Vital function of pesticides in agricultural production}

Pest and disease management has played its role in doubling food production in the last 40 years. Pesticides, as an important input substance in agricultural production, have made enormous contribution to the development of agriculture and food supply to mankind (Wang and Li 2007). Existing data indicate that one third (1/3) losses of the potential crop yield due to the pests' injure were avoided and recovered worldwide because of chemicals application (Liu et al. 2002). China, with only $7 \%$ of agricultural acreage of the world, has managed to provide food for $22 \%$ of the world population; thereinto, pesticides make a great contribution (Huang and Qiao 2002). Increased agricultural pesticide use nearly doubled food crop harvests from $42 \%$ of the theoretical worldwide yield in 1965 to $70 \%$ of the theoretical yield by 1990 . Unfortunately, $30 \%$ of the theoretical yield was still being lost because the use of effective pest management methods was not applied uniformly around the world and it still is not. Without pesticides, $70 \%$ of crop yields could have been lost to pests (Oerke 2005).

\subsection{Adverse effect of pesticides}

Pesticides play an important role in agricultural production, especially to increase crop yield and farmer's income though. However, it cannot be denied that adverse effects of pesticide application can be seen everywhere, and on human health and on the environment in and around intensive systems. The intensity of crop protection has increased considerably as exemplified by a 15-20-fold increase in the amount of 
pesticides used worldwide (Oerke 2005). Over the last century, agricultural production has steadily increased, mainly due to improved nutrient availability, crop breeding, and crop protection. However, these improvements have often caused environmental problems, such as water pollution, trace gas emissions, or soil degradation. More sustainable practices are needed to minimize the environmental impact of agricultural production and land use (Ludwig et al. 2011).

Both the production ability and application of pesticides of China were ranked first in the world at present. It brings a lot of issues, such as pollution and hazard which are more and more serious due to long-term slather pesticide, and causing the economic losses increase by years. Even more serious is that tens of thousands of people will experience toxicosis, injuries, and deaths (State Environmental Protection Administration 2001; Gao et al. 2002), especially when chemicals misuse. Chemicals misuse is defined as the "improper or incorrect use." Thus when an insecticide is used for the wrong target pests or at the wrong time, or both, it can be considered to be misused (Heong et al. 1995). Pesticides that were used in quantity lead to produce "three R" (i.e., resistance, residuce, and resurgence) increasingly severe (Wang and Li 2007). Table 1 shows the chemicals use of the major rice production provinces in China. The chemicals usage amount in unit area (in kilogram per hectare) varied from the lowest of $18.54 \mathrm{~kg} / \mathrm{hm}^{2}$ in Guizhou to highest of $87.68 \mathrm{~kg} / \mathrm{hm}^{2}$ in Liaoning in 2010. Table 2 indicated that the chemicals usage amount in unit area of the major counties in Jiangxi
Province, a middle-level developing province in central China.

\subsection{Resolve measures of side effect caused by pesticides}

Farmers are facing serious plant protection issues and phytosanitary risks, in particular in the tropics. Such issues are food insecurity, lower income in traditional low input agroecosystems, adverse effects of pesticide use on human health and on the environment in intensive systems, and export restrictions due to strict regulations on quarantine pests and limits on pesticide residues (Vandermeer et al. 1998). To provide more and better food to populations in both the southern and northern hemispheres in a sustainable manner, there is a need for a drastic reduction in pesticide use while keeping crop pest and disease damage under control (Ratnadass et al. 2012).

Due to increasing problems occurring from massive applications of pesticides, such as insect resistance to pesticides, the use of biotechnological tools to minimize losses from insect pests has become inevitable. Presenting alternative strategies for alleviating biotic stresses, biotechnological approaches for pest management and ecological sustainability explore how the modern tools of biotechnology can be used in pest management for sustainable crop production, the biosafety of transgenic crops, and environmental conservation.

Another way of reducing fungicide use is through cultural control. This includes all those techniques that will make the

Table 1 Rice production and chemicals use of the major provinces in China, 2009-2010

\begin{tabular}{|c|c|c|c|c|c|c|c|c|c|}
\hline \multirow[t]{2}{*}{ Rice growth regions } & \multirow[t]{2}{*}{ Provinces } & \multicolumn{5}{|l|}{ Year 2009} & \multicolumn{3}{|l|}{ Year 2010} \\
\hline & & $\begin{array}{l}\text { Rice } \\
\text { sown area } \\
\text { (thousand } \\
\mathrm{hm}^{2} \text { ) }\end{array}$ & $\begin{array}{l}\text { Rice } \\
\text { total output } \\
\text { (thousand } \\
\text { ton) }\end{array}$ & $\begin{array}{l}\text { Unit area } \\
\text { output } \\
\left(\mathrm{kg} / \mathrm{hm}^{2}\right)\end{array}$ & $\begin{array}{l}\text { Chemicals } \\
\text { usage amount } \\
\text { (thousand ton) }\end{array}$ & $\begin{array}{l}\text { Chemicals } \\
\text { usage amount } \\
\text { in unit area } \\
\left(\mathrm{kg} / \mathrm{hm}^{2}\right)\end{array}$ & $\begin{array}{l}\text { Rice } \\
\text { sown area } \\
\text { (thousand } \\
\mathrm{hm}^{2} \text { ) }\end{array}$ & $\begin{array}{l}\text { Chemicals } \\
\text { usage amount } \\
\text { (thousand ton) }\end{array}$ & $\begin{array}{l}\text { Chemicals } \\
\text { usage amount } \\
\text { in unit area } \\
\left(\mathrm{kg} / \mathrm{hm}^{2}\right)\end{array}$ \\
\hline \multirow[t]{3}{*}{ Southwest } & Sichuan & $2,027.1$ & 15,202 & 7,499 & 60.8 & 30.0 & $2,004.5$ & 62.2 & 31.0 \\
\hline & Guizhou & 698.2 & 4,532 & 6,490 & 12.9 & 18.5 & 695.8 & 12.9 & 18.5 \\
\hline & Yunnan & $1,039.8$ & 6,362 & 6,119 & 42.9 & 41.3 & $1,021.0$ & 46.2 & 45.3 \\
\hline \multirow[t]{3}{*}{ South China } & Guangdong & $1,953.7$ & 10,581 & 5,399 & 103.7 & 53.1 & $1,952.7$ & 104.4 & 53.5 \\
\hline & Guangxi & $2,125.0$ & 11,459 & 5,392 & 62.2 & 29.3 & $2,094.4$ & 64.5 & 30.8 \\
\hline & Fujian & 864.6 & 5,153 & 5,960 & 57.8 & 66.9 & 854.8 & 58.2 & 68.1 \\
\hline \multirow[t]{3}{*}{ Northeast } & Heilongjiang & $2,636.0$ & 15,745 & 6,313 & 66.8 & 25.3 & $2,768.8$ & 73.8 & 26.7 \\
\hline & Jilin & 660.0 & 5,050 & 7,647 & 42.4 & 64.2 & 673.5 & 42.8 & 63.6 \\
\hline & Liaoning & 657.0 & 5,060 & 7,710 & 54.1 & 82.3 & 677.5 & 59.4 & 87.7 \\
\hline \multirow[t]{3}{*}{ Central China } & Hunan & $4,047.2$ & 25,786 & 6,371 & 126.7 & 31.3 & $4,030.5$ & 118.8 & 29.5 \\
\hline & Hubei & $2,045.1$ & 15,919 & 7,784 & 127.9 & 62.5 & $2,038.2$ & 140.0 & 68.7 \\
\hline & Jiangxi & $3,282.1$ & 19,059 & 5,807 & 138.8 & 42.3 & $3,318.4$ & 106.5 & 32.1 \\
\hline \multirow[t]{3}{*}{ East China } & Jiangsu & $2,233.2$ & 18,029 & 8,073 & 90.1 & 40.4 & $2,234.2$ & 91.1 & 40.8 \\
\hline & Zhejiang & 938.7 & 6,667 & 7,102 & 65.1 & 69.4 & 923.2 & 65.8 & 71.3 \\
\hline & An'hui & $2,246.9$ & 14,056 & 6,256 & 116.6 & 51.9 & $2,245.4$ & 117.4 & 52.3 \\
\hline
\end{tabular}

Data come from China's agriculture yearbook, 2010 and 2011, Agricultural Publishing House of China, Beijing 
Table 2 Rice sown area and chemicals use dosage of major counties in Jiangxi Province (2010)

\begin{tabular}{|c|c|c|c|c|c|c|c|}
\hline $\begin{array}{l}\text { County } \\
\text { (city) }\end{array}$ & $\begin{array}{l}\text { Rice sown area } \\
\text { (thousand } \mathrm{hm}^{2} \text { ) }\end{array}$ & $\begin{array}{l}\text { Chemicals usage } \\
\text { amount } \\
\text { (million } \mathrm{kg} \text { ) }\end{array}$ & $\begin{array}{l}\text { Chemicals usage } \\
\text { amount in unit area } \\
\left(\mathrm{kg} / \mathrm{hm}^{2}\right)\end{array}$ & $\begin{array}{l}\text { County } \\
\text { (city) }\end{array}$ & $\begin{array}{l}\text { Rice sown } \\
\text { area (thousand } \\
\mathrm{hm}^{2} \text { ) }\end{array}$ & $\begin{array}{l}\text { Chemicals usage } \\
\text { amount } \\
\text { (million } \mathrm{kg} \text { ) }\end{array}$ & $\begin{array}{l}\text { Chemicals usage } \\
\text { amount in unit } \\
\text { area }\left(\mathrm{kg} / \mathrm{hm}^{2}\right)\end{array}$ \\
\hline Nanchang & 79.27 & 4.09 & 51.60 & Yushui & 30.53 & 1.03 & 33.73 \\
\hline Fengcheng & 78.07 & 2.60 & 33.30 & Yuanzhou & 30.47 & 0.77 & 25.27 \\
\hline Boyang & 67.13 & 1.95 & 29.05 & Xingan & 27.33 & 1.82 & 66.59 \\
\hline Gao'an & 61.13 & 2.45 & 40.08 & Anfu & 26.60 & 1.36 & 51.13 \\
\hline Xinjian & 57.53 & 1.58 & 27.46 & Jinxi & 25.33 & 1.05 & 41.45 \\
\hline Linchuan & 56.07 & 2.23 & 39.77 & Shanggao & 24.93 & 0.80 & 32.09 \\
\hline Yugan & 52.67 & 1.06 & 20.13 & Xingguo & 24.80 & 1.32 & 53.23 \\
\hline Zhangshu & 45.13 & 2.20 & 48.74 & Dongxiang & 24.80 & 2.22 & 89.52 \\
\hline Jishui & 41.67 & 2.03 & 48.72 & Yongxin & 23.40 & 0.73 & 31.20 \\
\hline Jinxian & 38.93 & 0.88 & 22.60 & Yifeng & 21.80 & 0.69 & 31.65 \\
\hline Taihe & 38.00 & 0.98 & 25.79 & Xinfeng & 21.60 & 0.80 & 37.04 \\
\hline Ningdu & 32.20 & 1.79 & 55.59 & Yujiang & 20.33 & 1.35 & 66.39 \\
\hline Leping & 31.80 & 1.55 & 48.74 & Wan'an & 20.27 & 1.35 & 66.61 \\
\hline Duchang & 31.20 & 1.04 & 33.33 & Average & & & 42.60 \\
\hline
\end{tabular}

Data come from Jiangxi provincial agriculture yearbook, 2011

environment less favorable for pests to develop or multiply, but which still favors rice production. Cultural practices, such as rotations, cultivar mixtures, crop mosaics, and planting times have been part of the local practice in many ricegrowing areas (Oka 1988). Flooding, stubble burning, fallow, intercropping, terracing, and plant spacing are other practices that have been used by rice farmers for centuries to help in producing a good crop (Bray 1990; Thurston 1990). With the support of state- and provincial-level projects, several approaches have been considered to control rice pests in more than ten provinces of China (view Fig. 1, the map of China) from 2004 to 2011 . The aim of the study was to effectively control rice pests while maintaining rice yield and producing high quality products. Several nonchemical approaches for controlling rice diseases, insect pests, and weeds have been studied and applied, specifically:

(1) Using rice resistance genomic diversity to control rice blast (Pyricularia oryzae) and plant hoppers (Nilaparvata lugens Stål, Sogatella furcifera Horvath).

(2) Changing rice seeding time, transplanting date to reduce diseases and pests injures to rice.

(3) Rearing fish and frog (bullfrog) in rice paddy fields to control plant hoppers, rice sheath blight (Rhizoctonia solani), and weeds.

(4) Rearing ducks in rice paddy fields to control rice plant hopper, stem borer, sheath blight, and weeds.

(5) Soaking rice seeds in biogas fermentative liquid and cultivating seedlings with biogas fermentative residues.

(6) Using a Jiaduo Frequoscillation Pest-killing Lamp to control rice insect pests.

\section{Rice pests management by mixed growth of different resistance rice varieties}

\subsection{Disease management through genetic diversity}

Actually, there are already extensive reviews of the ways intraspecific crop diversity nearly always reduces yield losses caused by pathogens (Zhu et al. 2000; Ngugi et al. 2001; Mundt 2002; Castilla et al. 2003; Cox et al. 2004), and sometimes by pests (Teetes et al. 1994; Johnson et al. 2006). Vilich-Meller (1992) reported that wheat-barley mixtures resulted in greater disease reduction in wheat than did applications of fungicide, illustrating the potential benefit of mixing cereal species in organic agriculture (Kaut et al. 2008). Polycultures of interplanted crops often support fewer pests at lower densities than monoculture and tend to increase number of natural enemies (Ludwig et al. 2011).

Intercropping can play an important role in reducing insect pest infestation (Root 1973; Potts 1990). Van Emden and Wratten (1990) have given a number of examples of the effect of intercropping on insect population densities. Intercropping may reduce pest damage by attracting pests to a less valuable crop or one where the pest is less serious (van Emden 1989).

Andow and Hidaka (1989) found that traditional varieties grown under organic culture in Japan had less disease and lower arthropod populations than conventional farms growing high-yielding cultivars. Methods to mix host genes by deploying these genes either in pyramids in the same cultivar, as multilines, or as multivars (mixtures of cultivars, each with a different gene for resistance) may be useful in disease management. 


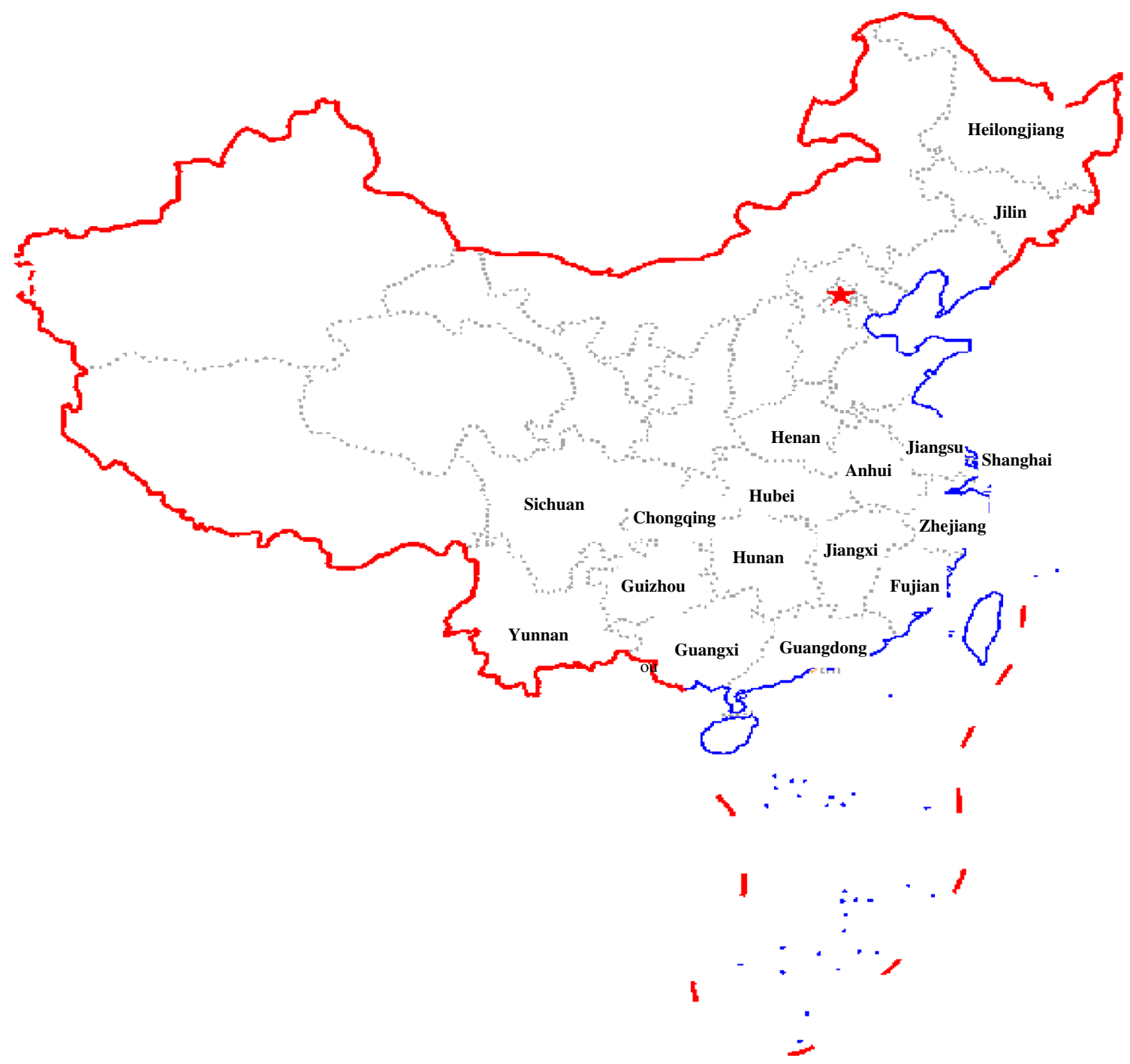

Fig. 1 China map showing the provinces where the project was carried out

In this study, the blast-resistant hybrid rice combinations Chuanxiangyou 2, Ilyou 7, and Yixiangyou and susceptible glutinous rice were selected. The experiments and production practices were conducted in Yunnan (Zhu et al. 2003; 2004a, b; Lü and Zhou 2004), Guizhou (Wu 2011; Feng et al. 2007), Sichuan (Mao et al. 1991; Zhao and Liao 2006), and Hunan (Liu et al. 2003). The varieties were large-scale grown in mixture ratios of $5: 1,4: 1,3: 1,2: 1,1: 1,1: 2$, and $1: 3$. Investigations of panicle neck blast were carried out at yellow ripeness stage. Results indicated that mixtures grown at different ratio of resistance to susceptible varieties showed significantly different of disease control effects. The control efficiency to panicle blast was $52.1-88.4 \%$ without any chemical application in the experiments and large-scale production practices. According to the mixture ratio of resistance and susceptible varieties, control efficiency decreased with the increase of susceptible varieties. The average control efficiency to panicle blast reached $88.4 \%$ in the $5: 1-4: 1$ of resistance to susceptible mix growth models.
The experiments in Jilin Province also showed the same results of above provinces (Ren et al. 2004; Gan and Lou 2008). Control efficiency to panicle blast differed significantly for different resistance variety mixed plantings. When the resistant variety of japonica Songjing 6 was mixture grown with susceptible variety Jiyou 1 by the ratio of 5:1, the panicle blast ratio of Jiyou 1 decreased from $68.9 \%$ (when it was planted alone) to $2.8 \%$, and the control efficiency reached $95.9 \%$. The leaf blast was not surveyed in the both experiments and production practice.

From the survey results during 1998-2003 in Yunnan Province, the mean disease incidence for traditional varieties (susceptible) in mixture decreased $72.0 \%$ and the mean disease index decreased $75.4 \%$ than monoculture. For modern varieties (resistance), the mean disease incidence in mixture decreased $32.4 \%$ and the mean disease index decreased $48.2 \%$ than monoculture.

The results during 2002-2003 in Sichuan Province showed that the mean disease incidence for glutinous varieties in 
mixture decreased $58.1 \%$ and the mean disease index decreased $67.4 \%$ than monoculture. For modern varieties, the mean disease incidence in mixture decreased $28.6 \%$ and the mean disease index decreased $35.5 \%$ than monoculture. Because of different eco-environment of the planting regions and the different resistance of involved varieties, the effects of blast control had larger difference among different regions and different variety combinations, but the effects of mixture planting for blast control were all higher than that of corresponding monoculture. It indicated that mixture planting can be universally adopted (Zhu et al. 2003, 2004a, b).

\subsection{Control efficiency of plant hoppers by inheritance diversity}

Compared with resistance and susceptible varieties separately planted, the amount of adult plant hopper migrated into the fields, and egg laying amount per female show no significant differences when insect resistance variety RHT was mixed grown with susceptible variety TN1 in a 2:1 ratio. However, the nymph density of 100-hill and the average appetite per female plant hopper (measured by excretive honeydew) were significantly lower than that of the susceptible variety planted alone.

\subsection{Effects of mixture planting on rice yield}

From the survey results during 1998-2003 in Yunnan Province, the average yield of traditional varieties in mixture increased $4,753.52 \mathrm{~kg} / \mathrm{hm}^{2}$ and $117.4 \%$ higher than that of monoculture. The average yield of modern varieties in mixture increased $748.29 \mathrm{~kg} / \mathrm{hm}^{2}$ and $9.39 \%$ higher than that of monoculture. The results during 2002-2003 in Sichuan Province showed that the average yield of modern varieties in mixture increased $534-600 \mathrm{~kg} / \mathrm{hm}^{2}$ and $6.74-7.48 \%$ higher than that of monoculture. The average yield of glutinous varieties in mixture increased $3,270-3,303 \mathrm{~kg} / \mathrm{hm}^{2}$ and $61.1-64.2 \%$ higher than that of monoculture.

Mixed grown of blast resistant and susceptible varieties increased rice output compared with resistant or susceptible varieties planted alone. Yields of mixed grown resistant and susceptible rice variety increased from 6.92 to $8.73 \%$ compared with that of separate plantings, respectively, viz. $631.5-955.0 \mathrm{~kg}$ of rice yield increased per hectare. At the same time, two times of chemical application for controlling blast were reduced. The average income of mixed grown of different resistance varieties increased by 1500 RMB $¥$ ( $¥$ from here onwards) per hectare due to the increased yield, reduction in chemicals used, and savings in time and labor (Zhu et al. 2003, 2004a, b; Liu et al. 2003).

The results indicated that the control efficiency to rice panicle blast vary from region to region, year to year, and variety to variety because the diseases were affected by multiple factors. This agricultural system increases rice yield both of the resistant and susceptible varieties, particularly to increase the yield of susceptible varieties drastically than that of their monoculture.

\section{Adjusting rice seeding and transplanting date to reduce pest injuries}

\subsection{Effect of seeding and transplanting date on insect pests}

Experiments were carried out in Sichuan, Hubei, Jiangsu, and Zhejiang. Pest injury to rice can be significantly reduced by using crop rotation and intercrops, by modifying ecological conditions, and by changing the seeding and transplanting dates. In Sichuan, Hubei (Zhang et al. 2009a, b), and Zhejiang (Zhu et al. 2011a, b), rice seeding dates of March 5 and March 20 were selected, and rice plants infested by stem borers (Chilo suppressalis (Walker) and Tryporyza incertulas (Walker)) were investigated. The infestation ratio of rice plants by first generation of stem borers on the earlier seeding date (March 5) was $8.33 \%$, while the later seeding date (March 20) demonstrated a less severe infestation of $2.15 \%$. Furthermore, the infestation ratio by the third generation of stem borers on March 5 and March 20 were 44.4 and $7.72 \%$, respectively, indicating that intensity of early seeded rice infestation was 5.78 times higher than that of the late seeded crops.

Results also showed that rotation of irrigated crop (rice) and dry land crops (e.g., vegetable, strawberry, potato, or soybean) reduced the rice injury ratio of sheath blight and stem borer by 60.3 and $30.0 \%$, respectively, compared with continuous irrigated rice.

In Jiangsu, the japonica variety of 9915 was chosen to investigate the effect on stem borer of different seeding dates. May 4-6 was the traditional seeding date of single season rice at local, in this experiment, the seeding date was postponed. Six seeding dates of May 10, 14, 17, 20, 23, and 26 were selected; the seedlings were transplanted 30 days after seeding, so six corresponding transplanted dates were June $9,13,16,19,22$, and 25, respectively (Table 3). The data were analyzed according to Tang Qiyi's DPS and the Statistical Soft Ware (Tang 2007). Rice injured of the traditional seeding date (May 4-6) were more severe compare with the six seeding and transplanting dates caused by stem borers. Generally, the earlier seeding and transplanting date exhibited more serious injuries, and the postponed rice seeding and transplanting dates had reduced injuries. In Jiangsu Province, a good control efficiency to stem borer in relation to optimal seeding and transplanting date of single season rice was May 20-23 and June 20-26, respectively (Sun et al. 2002). 
Table 3 Effect of stem borer on rice for different seeding and transplanting date

Seeding date Transplanting Egg piece density after seeding

$\begin{array}{lll}\text { (month/day) } & \text { date (month/day) } & \left.\text { (egg piece } / \mathrm{hm}^{2}\right)\end{array}$

10 days 20 days 30 days Average

Dead heart ratio Infested by second generation Infested by third generation in transplanting date $(\%)$

\begin{tabular}{ll}
\hline $\begin{array}{l}\text { Dead heart } \\
\text { ratio (\%) }\end{array}$ & $\begin{array}{l}\text { Remnant } \\
\text { stem borers } \\
\left(\text { larva/hm } / \mathrm{hm}^{2}\right)\end{array}$ \\
\hline
\end{tabular}

\begin{tabular}{ll}
\hline White panicle & Remnant \\
ratio (\%) & $\begin{array}{l}\text { stem borers } \\
(\text { larva/hm²) }\end{array}$
\end{tabular}

\begin{tabular}{lllllllllll}
\hline $5 / 10$ & $6 / 9$ & 1,290 & 12,840 & 6,120 & $6,750 \mathrm{a}^{\mathrm{a}}$ & $5.24 \mathrm{a}$ & $5.03 \mathrm{a}$ & $8,400 \mathrm{a}$ & $15.8 \mathrm{a}$ & $53,400 \mathrm{a}$ \\
$5 / 14$ & $6 / 13$ & 2,340 & 11,280 & 5,550 & $6,390 \mathrm{a}$ & $3.63 \mathrm{~b}$ & $5.12 \mathrm{a}$ & $8,400 \mathrm{a}$ & $15.9 \mathrm{a}$ & $53,730 \mathrm{a}$ \\
$5 / 17$ & $6 / 16$ & 2,235 & 5,970 & 4,800 & $4,335 \mathrm{a}$ & $1.89 \mathrm{c}$ & $4.14 \mathrm{~b}$ & $5,850 \mathrm{~b}$ & $9.64 \mathrm{~b}$ & $43,350 \mathrm{~b}$ \\
$5 / 20$ & $6 / 19$ & 2,430 & 2,040 & 2,550 & $2,340 \mathrm{~b}$ & $1.83 \mathrm{c}$ & $3.62 \mathrm{~b}$ & $4,290 \mathrm{c}$ & $5.63 \mathrm{c}$ & $29,407 \mathrm{c}$ \\
$5 / 23$ & $6 / 22$ & 2,235 & 840 & 570 & $1,335 \mathrm{~b}$ & $1.25 \mathrm{~d}$ & $2.89 \mathrm{c}$ & $2,340 \mathrm{~d}$ & $4.90 \mathrm{~d}$ & $16,809 \mathrm{~d}$ \\
$5 / 26$ & $6 / 25$ & 1,875 & 585 & 60 & $840 \mathrm{~b}$ & $1.12 \mathrm{~d}$ & $1.14 \mathrm{~d}$ & $2,130 \mathrm{e}$ & $3.70 \mathrm{e}$ & $13,389 \mathrm{e}$ \\
\hline
\end{tabular}

${ }^{a}$ Values followed by common letters within a column are not significantly different at $P=0.05$ level. All data were analyzed according to "Tang (2007). The following tables are the same.

\subsection{Effect of seeding and transplanting date on sheath blight}

The occurrence of rice sheath blight ( $R$. solani) was also markedly influenced by seeding and transplanting date. In Sichuan, the disease index of sheath blight was 39.6 when the sowing date was March 5, but the index decreased to 11.8 when the seeding date was postponed to March 20.

Experiments on the relativity of seeding (transplanting) date and sheath blight severity were carried out in 2006 and 2007 at the experimental base of CNRRI, Hangzhou, Zhejiang (Huang et al. 2009a). Three seeding date of May 12 and 23 and Jun 2 was selected, and corresponding three transplanting dates after 20 days of seeding. Moderately susceptible to sheath blight super hybrid rice Guodao6 and moderately resistant Liangyoupeijiu were chosen as the testing hybrid rice combinations. Each treatment had three replicates and with the area of $50 \mathrm{~m}^{2} /$ plot. Investigations on sheath blight were carried out August 15 and September 25. Two-year average values are shown in Table 4. The results showed that the disease indices of late seeding (June 2) and transplanting (June 22) were significantly lower than that of early seeding (May 12) and transplanting (June 1) for both Guodao6 and Liangyoupeijiu super hybrid rice combinations. The sheath blight disease indices were quite low when the seeding and transplanting dates were postponed to June 2 and June 22, respectively, because of rice growth stage that was susceptible to sheath blight avoiding the weather condition in favor of the disease. When the seeding and transplanting dates of Guodao6 and Liangyoupeijiu were the same, the severity of sheath blight of Guodao6 was more serious than that of Liangyoupeijiu, which indicated that Guodao6 was more susceptible to sheath blight than that of Liangyoupeijiu. Table 4 also show that sheath blight intensity of Guodao6 for late seeding (May 23) had a significantly lower disease indices than that of early seeding (May 12) of Liangyoupeijiu though the former was more susceptible to sheath blight. The results indicated that the occurrence of sheath blight was significantly affected by seeding and transplanting date as well as weather conditions during the rice growing period.

\section{Releasing fish and frog in rice paddy field to control pests}

Rearing fish and frog in paddy field cannot only effectively controls insect pests and weeds but also increase

Table 4 Comparison of rice sheath blight for different seeding and transplanting dates of super hybrid rice combinations

\begin{tabular}{|c|c|c|c|c|c|c|c|}
\hline \multirow{2}{*}{$\begin{array}{l}\text { Super hybrid rice } \\
\text { combinations }\end{array}$} & \multirow{2}{*}{$\begin{array}{l}\text { Seeding date } \\
\text { (day/month) }\end{array}$} & \multirow{2}{*}{$\begin{array}{l}\text { Transplanting } \\
\text { date }(\mathrm{D} / \mathrm{mM})\end{array}$} & \multirow{2}{*}{$\begin{array}{l}\text { Heading } \\
\text { date }(\mathrm{D} / \mathrm{M})\end{array}$} & \multirow{2}{*}{$\begin{array}{l}\text { Flowering } \\
\text { date }(\mathrm{D} / \mathrm{M})\end{array}$} & \multirow{2}{*}{$\begin{array}{l}\text { Dough grain } \\
\text { date }(\mathrm{D} / \mathrm{M})\end{array}$} & \multicolumn{2}{|c|}{ Disease index of sheath blight } \\
\hline & & & & & & 15/Aug & 25/Sept \\
\hline \multirow[t]{3}{*}{ Guodao 6} & $\mathrm{~A}: 12 / 5$ & $1 / 6$ & $12 / 8$ & $16 / 8$ & $20 / 9$ & $41.6 \mathrm{a}$ & $45.2 \mathrm{a}$ \\
\hline & $\mathrm{B}: 23 / 5$ & $12 / 6$ & $17 / 8$ & $21 / 8$ & $26 / 9$ & $9.35 \mathrm{c}$ & $20.5 \mathrm{c}$ \\
\hline & $\mathrm{C}: 2 / 6$ & $22 / 6$ & $18 / 8$ & $24 / 8$ & $5 / 10$ & $2.07 \mathrm{e}$ & $5.14 \mathrm{~d}$ \\
\hline \multirow[t]{3}{*}{ Liangyoupeijiu } & $\mathrm{A}: 12 / 5$ & $1 / 6$ & $14 / 8$ & $18 / 8$ & $22 / 9$ & $35.4 \mathrm{~b}$ & $39.9 \mathrm{~b}$ \\
\hline & $\mathrm{B}: 23 / 5$ & $12 / 6$ & $24 / 8$ & $28 / 8$ & $9 / 10$ & $4.72 \mathrm{~d}$ & $5.33 \mathrm{~d}$ \\
\hline & $\mathrm{C}: 2 / 6$ & $22 / 6$ & $30 / 8$ & $2 / 9$ & $14 / 10$ & $0.00 \mathrm{f}$ & $1.33 \mathrm{e}$ \\
\hline
\end{tabular}


comprehensive benefits to a great extent. For example, grass carp (Ctenopharyngodon idellus) feeds on young weeds, frogs prey on larva or nymph of insects. From 2007 to 2010, experiments and demonstrations were carried out in Chongqing, Jiangxi, and Zhejiang (Zhou and Zhang 2011; Zhu 2000; TEMSAPZP 2012). Native frog (tiger frog, Hoplobatrachus rugulosus) and grass carp were used in fields during the early and middle rice growing seasons (April to June) and bullfrog (Rana catesbiana) were released in the late rice growing season to eliminate pests. The animals feed on pests, with one adult bullfrog able to eat more than 100 insects per day. Compared with not releasing fish, frog, and bullfrog paddy, dead heart of rice plants and white panicle ratio caused by stem borers (C. suppressalis, Scirpophaga incertulas) were reduced by $62.9-83.4 \%$ and $58.3-84.8 \%$, respectively. The plant hoppers amount of 100-hill and the density of weeds per square meter were reduced by 38.9 and $41.7 \%$, respectively. The number of injured tillers decreased by $21.8 \%$, and pesticide application was reduced twice (Figs. 2a, b and 3).

Seven thousand five hundred fishes were released in 1 ha combined with the use of "lü lang" (or green wave, a biological pesticide with low toxicity) to control leaf folder and plant hoppers, and $5 \%$ Jinggangmycin (a biological fungicide) 3, $000 \mathrm{~mL}+20 \%$ Tricyclazole $1,500 \mathrm{~g}$ to control sheath blight and blast. The results showed that the injured ratio of rice hill by leaf folder and the number of plant hoppers $(N$. lugens, Sogatella furcifera) per 100-hill were significantly reduced compared with that of no fishes and frogs were released. Compare with no fishes and frogs, rice yield of releasing fishes and frogs increased by $10.1 \%$; moreover, $1,180 \mathrm{~kg}$ of fish and frogs were harvested per hectare (Peng 2012; Huang and Huang 2012; Wang 2004). Very good economic, ecological, and social benefits were gained from this rice cropping pattern, as shown in Table 5.

\section{Rearing duck in paddy field to control pests}

Using the duck's habits of eating pests and young weeds, and excreting feces as fertilizer, releasing duck in rice paddy field can effectively controlled rice pests, reduced the application

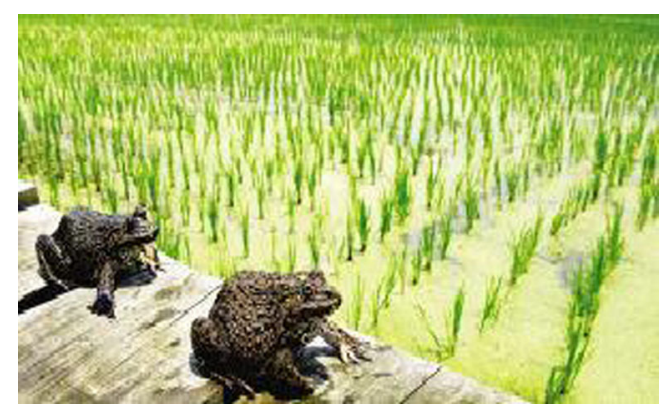

Frogs in paddy field

Fig. 3 Frogs in paddy field

dosage of fertilizer and chemicals, decreased environmental pollution, and increased rice yield and quality and farmers' income (Deng et al. 2007; Deng and Pan 2008; Yu et al. 2008a; Zhang et al. 2009c). More than 500,000 ha of rice paddy fields were established with rice-duck mutualism to control pests in southern China (Zhang et al. 2009c), Yunnan (Peng et al. 2002), Jiangxi (Li et al. 2004), Hunan (Wang and Huang 2002; Liu et al. 2006), Hubei (Lin and Jin 2002), Anhui (Zhu et al. 2001; Zhen et al. 2004; Wang et al. 2004), Zhejiang (Yu and Jin 2006; Yu et al. 2004a, b, 2005, 2008a, b), Jiangsu (Wei et al. 2005), Shanghai (Zheng et al. 1997), Henan (Zhang et al. 2002), Heilongjiang (Asano 2000), and Jilin (Jin et al. 2009; Hou et al. 2009) from 2005 to 2011. The control efficiency of rice insect pests, diseases, and weeds by releasing ducks in paddy fields was investigated in more than 12 provinces (cities).

At rice active (maximal) tillering stage, 225-375 young ducks ( 20 days old) per hectare were released to the paddy and allowed to mutualism for 50-60 days. Generally, an adult duck (weight over $1.0 \mathrm{~kg}$ ) can ate more than 150 pests (including few natural enemies) per day. The investigated average results show that the total number of insects in released duck fields (the followings abbreviated duck fields) reduced by $87.7 \%$ compared with non-duck fields. Plant hoppers and leaf folder were reduced by 37.6 and $48.3 \% 1$ day after ducks were released compared with the day before release.

In Zhejiang, the experiments' results showed that the total number of plant hoppers and leafhopper in duck fields were reduced by 63.9 and $77.3 \%$, and weeds were reduced by 50.6
Fig. 2 a Fish in paddy field. b Harvest fish

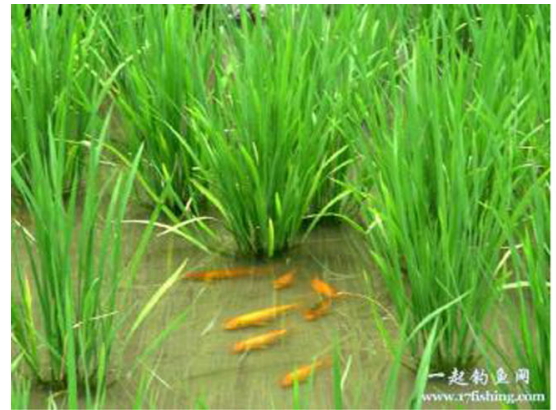

a Fish in paddy field

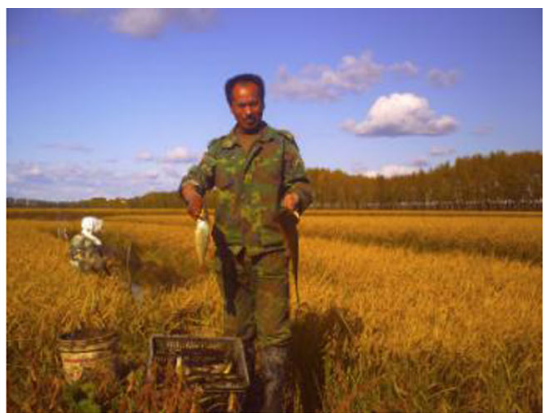

b Harvest fish 
Table 5 Effect on rice pests of rice-fish and frog coexisting rice paddy system

\begin{tabular}{lrlcr}
\hline Content & $\begin{array}{l}\text { Plant } \\
\text { hoppers } \\
\text { 100-hill }\end{array}$ & $\begin{array}{l}\text { Infected } \\
\text { hill ratio } \\
(\%)\end{array}$ & $\begin{array}{l}\text { Rice yield } \\
\left(\mathrm{kg} / \mathrm{hm}^{2}\right)\end{array}$ & $\begin{array}{l}\text { Fish and } \\
\text { frog yield } \\
\left(\mathrm{kg} / \mathrm{hm}^{2}\right)\end{array}$ \\
\hline Fish and frog & 280.0 & 10.2 & $9,180.0$ & $1,177.5$ \\
No fish and frog & $2,150.0$ & 34.6 & $8,337.0$ & $\begin{array}{r}0.00 \\
\text { Efficiency (\%) }\end{array}$ \\
\hline
\end{tabular}

and $94.2 \% 12$ and 42 days after ducks were released compared with non-duck fields, respectively. The sheath blight disease incidence at maximal tillering and full heading stage decreased by 67.2 and $52.5 \%$ compared with the non-duck fields, respectively, and the quantity of natural enemy of spiders in duck fields were 1.66-2.61 times than that in nonduck fields. This indicated that pests were effectively controlled in duck fields compare with non-duck fields (Fig 4). The pests control effects of native and hybrid ducks were also tested. During the maximal tillering and full heading stages, pests control by native duck was 66.8 and $73.9 \%$, and hybrid duck was 60.7 and $80.8 \%$, respectively.

Rice-duck farming agro-ecosystem reduced $30.6 \%$ fertilizers and $59.4 \%$ pesticides compare with conventional farming system. The quality of rice produced in rice-duck mutualism was significantly improved due to no herbicide and less pesticide was applied (Yu et al. 2008a; Zhang et al. 2009c). According the China State Standard of Rice (GB/T 1789, 1999), coarse rice rate, head rice rate, gel consistency, and chalkiness rate of rice produced in rice-duck farming were superior to traditional farming (Wang et al. 2004). The contents of malathion, phosphide, chloride, arsenic(As), mercury $(\mathrm{Hg})$, benzex, and DDT of duck field rice were obviously lower than the contents of the national regulation values (Li et al. 2003). Rice produced in rice-duck mutualism fields almost had no pollution with pesticides and fertilizer (Zhang et al. 2002). Compare with rice monoculture, rice yield of rice-duck mutualism system increased $4.42 \%$. However, the rice quality improved and economic benefits increase by 2 , 000-4,500 $¥$ per hectare through ducks sale (Zhang et al. 2002; Deng et al. 2007; Deng and Pan 2008). In Zhejiang Province, a total area of 86.4 thousand hectares of rice-duck mutualism were implemented from 2001 to 2003. Compared with traditional rice farming, duck fields increase 3,404.1 $¥$ per hectare because of increasing revenue and reducing expenditure, grain yield increased $295.5 \mathrm{~kg}$ per hectare. The total income add up to 294 million $¥$ and increased 25,000 tons grain (Yu et al. 2004a, b).

\section{Seeds soaking with biogas fermentative liquid (BFL) and seedling cultivation with biogas fermentative residues (BFR)}

To study the effects of biogas manure on rice, rice seeds were soaked with biogas liquid, and rice seedlings were treated with biogas residues (manure). The results showed that (1) seeds germination was promoted and seedling quality was enhanced when rice seeds were soaked with biogas liquid; (2) when biogas manure was combined with a small amount of chemical fertilizer and applied in paddy fields, the soil organic matter and nutrient elements such as $\mathrm{N}, \mathrm{P}$, and $\mathrm{K}$ were increased and the ability of rice in taking up $\mathrm{N}$ and $\mathrm{P}$ nutrients was improved (Xiong et al. 1996); (3) injured rice caused by diseases and insect pests reduced when biogas manure was applied; (4) biogas manure not only increase rice grain yield but also improved rice quality, such as the grain appearance was better and nutrition content more plentiful; (5) using biogas manure on rice reduced production costs and decreased environmental pollution caused by chemical fertilizers application.

\subsection{Seeds soaked with biogas liquid}

Compared with the seeds soaked in fresh water, rice seeds soaked in biogas liquid for 24-48 h, and then washed with clear water, aerated, germinated, and seeded had germination rate increased by $5-10 \%$, seedlings emerged $1-2$ day earlier, and the seedling survival rate increased by $10-20 \%$. When rice seeds were soaked with biogas liquid, the seedlings grow healthy and strong, seedlings revive faster, and tiller earlier than that of water soaked. Compared with seeds soaked with fresh water, rice yield of seeds soaked with biogas liquid increased by $5-10 \%$ (Cao 1999; Wang et al. 2003), Fig. 5a.
Fig. 4 Ducks in paddy fields at early and late growth stage of rice. Download from www.ooopic. com (left) and www.zsnews.cn (right)
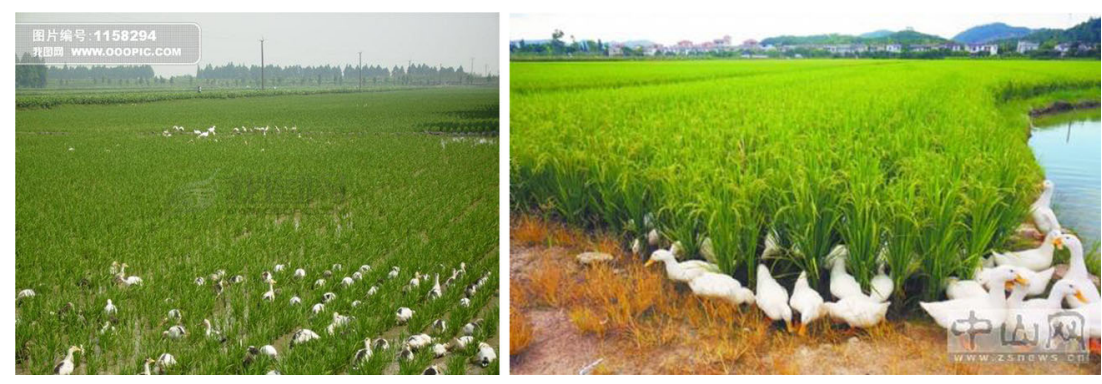
Fig. 5 a Seeds soaked with biogas fermentative liquid (BFL) $(1,2)$, with chemicals $(3)$ and control (4, with fresh water). b Mature stage of rice seeds soaked with BFL (left) and control (right, seeds soaked with water)

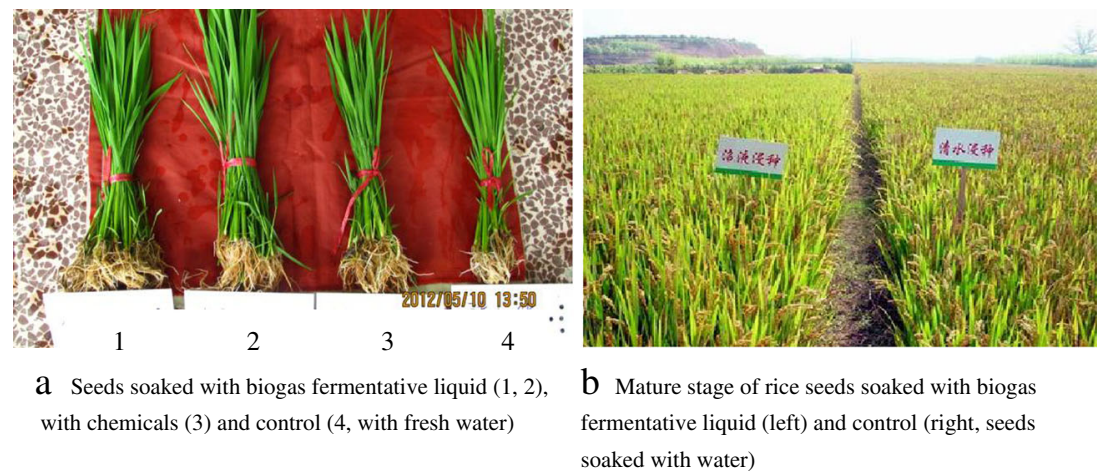

\subsection{Rice seedling cultivation with biogas residues}

Rice seeds soaked with biogas liquid and combined with seedling cultivation using biogas residues, the results showed that the seedlings quality was significantly improved, and injured seedlings by diseases decreased. The occurrence date of the diseases, such as bacterial leaf blight (Xanthomonas oryzae pv. oryzae) and blast (Pyricularia grisea), was postponed than that of chemical fertilizer treatment. When rice seedlings were cultivated with biogas residues, the natural control effect on bacterial leaf blight was better than that of using fertilizer and pig manure. The injured rice plants, leaves, and disease index of biogas residues treatment were reduced by $82.0 \%, 77.2 \%$ and 72.7 compared with the chemical treatment, respectively, and decreased by $58.5 \%, 53.6 \%$ and 50.3 compared with pig manure treatment, respectively (Cao 1999; Wang et al. 2003; Zhang et al. 2001).

When biogas residues was applied in paddy fields, the density of rice plant hoppers, leafhoppers, the occurrence rate of leaf folder, and rice sheath blight disease index reduced compared when chemical fertilizer and pig manure were used. Plant hoppers decreased by 59.0 and $69.0 \%$ and leafhoppers decreased by 66.0 and $54.0 \%$ in early and late rice, respectively, and sheath blight disease index were reduced by 45.0 66.5 (Zhang et al. 1996, 2008; Sun and Zhu 1990; Sun et al. 1999; Dai et al. 2000), Fig. 5b.
Fig. 6 a Old model of Jiaduo frequoscillation pest-killing lamp, with manual control of light; the killed insects were collected in the bag. b New model of Jiaduo frequoscillation pest-killing lamp, with power supplied by solar energy and automatic control of light and temperature

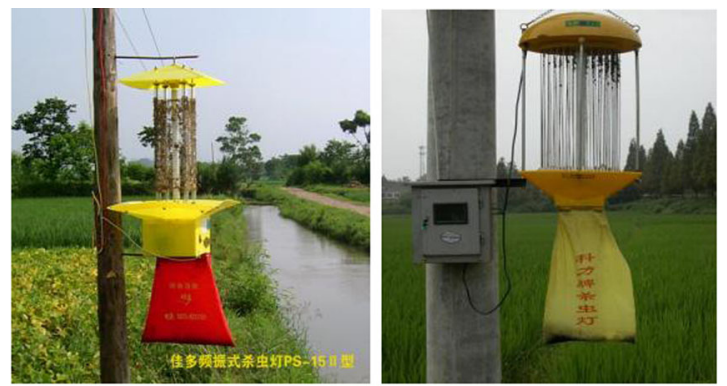

a Old model of Jiaduo frequoscillation pest-killing lamp, with manual control of light, the killed insects were collected in the bag
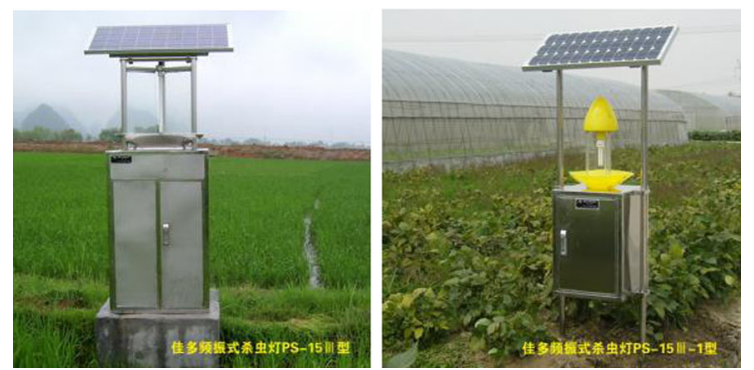

b New model of Jiaduo frequoscillation pest-killing lamp, with power supplied by solar energy and automatic control of light and temperature 


\section{Rice insect pests control by Jiaduo Frequoscillation Pest-killing Lamp}

A Jiaduo Frequoscillation Pest-killing Lamp ("pest-killing lamp" hereafter) (Henan Jiaduo Science and Industry Trade
Company, China) is a physical device used to trap insects based on phototaxis, the strong attraction to light, waves, and colors. The wavelength, wave band, and frequency of light are set in special scopes, with nearby pests trapped with light and color. High voltage wires then electrocute the pests, which fall

Table 6 Species, amounts, and main peak days of rice insect pests occurrence

\begin{tabular}{|c|c|c|c|c|c|}
\hline Order & Family & Amounts & Species & Trapped amounts & $\begin{array}{l}\text { Main peak day } \\
\text { (month/day) }\end{array}$ \\
\hline \multirow[t]{5}{*}{ Orthoptera } & Catantopidae & 1 & Oxyavelox (Fabricius) & 2 & \\
\hline & Pyrgomorphidae & 2 & Airactomorpha sirnensis I Bolirvdr & 3 & \\
\hline & Tettigoniidae & 3 & Conocephalus gladiatus Redtenbacker & 4 & \\
\hline & Gryllidae & 4 & $\begin{array}{l}\text { Teleogryllus occipitalis } \\
\text { (Audinet-Serville) }\end{array}$ & 29 & \\
\hline & Gryllotalpidae & 5 & Gryllotalpa orientalis Burmeister & 72 & \\
\hline \multirow[t]{10}{*}{ Homoptera } & Cicadellidae & 6 & Tettigella spectra (Distant) & 126 & \\
\hline & & 7 & Nephotettix cincticeps (Uhller) & 258 & \\
\hline & & 8 & Inazuna dorsalis (Motschulsky) & 1,582 & $9 / 11$ \\
\hline & & 9 & Empoasca flavescens (Fabricius) & 987 & \\
\hline & & 10 & Inemadara oryzae (Matsumura) & 562 & \\
\hline & & 11 & Telligella viridis (Linne) & 111 & \\
\hline & & 12 & Thaia rubiginosa Kuoh & 363 & \\
\hline & & 13 & Nephotettix vireseens (Distant) & 205 & \\
\hline & Delphacidae & 14 & Sogatella furcifera (Horvath) & 2,014 & $9 / 14$ \\
\hline & & 15 & Nilaparvata Lugens (Stal) & 1,366 & $9 / 14$ \\
\hline \multirow[t]{3}{*}{ Hemiptera } & Coreidae & 16 & Leptocorisa acuta Thunberg & 31 & \\
\hline & & 17 & Cleus punctiger Dallas & 7 & \\
\hline & Pentatomidae & 18 & Ezara viridula (Linnaeus) & 72 & \\
\hline \multirow[t]{22}{*}{ Lepidotera } & Pyralidae & 19 & Cnaphaloctocis medinalis Guenee & 554 & $8 / 31,9 / 18$ \\
\hline & & 20 & Susumia exgua (Butler) & 6 & \\
\hline & & 21 & Tryporyza mivella Fabricius & 2 & \\
\hline & & 22 & Tryporyza incertulas (Walker) & 501 & $10 / 2$ \\
\hline & & 23 & Chilo suppressalis (Walker) & 9 & \\
\hline & & 24 & Chilotraea auricilia (Dudgeon) & 11 & \\
\hline & & 25 & Nympgula depunctalis (Guenee) & 7 & \\
\hline & & 26 & Nymphula flucyuosalis Zeller & 13 & \\
\hline & & 27 & Ancylolomia japonica Zeller & 16 & \\
\hline & & 28 & Talanga sexpunctalis Moore & 4 & \\
\hline & & 29 & Aulacodes sinensis Hampson & 3 & \\
\hline & Noctuidae & 30 & Naranga aenescens Moore & 5,084 & $9 / 10,9 / 19$ \\
\hline & & 31 & Prodenia litura Fabricius & 133 & \\
\hline & & 32 & Spodoptera mauritia (Boisduval) & 92 & \\
\hline & & 33 & Sesamia inferens Walker & 22 & \\
\hline & & 34 & Leucania separate Walker & 13 & \\
\hline & & 35 & Leucania venalba Moore & 8 & \\
\hline & & 36 & Leucania Loreyi (Duponchel) & 6 & \\
\hline & Hypercompe & 37 & Creatonotus tronsiens (Walker) & 306 & \\
\hline & Lymantriidae & 38 & Porthesia scintillans (Walker) & 130 & \\
\hline & Hesperiidae & 39 & Pelopidas agna Moore & 5 & \\
\hline & Satyridae & 40 & Melaniitis leda (Linnaeus) & 4 & \\
\hline Diptera & Cecidomyiidae & 41 & Orseolia oryzae (Wood-Mason) & 144 & \\
\hline
\end{tabular}


Table 7 Control efficiency of leaf folder by pest-killing lamp

\begin{tabular}{|c|c|c|c|c|c|c|c|c|}
\hline Treatments & $\begin{array}{l}\text { Moth amount } \\
\text { per } \mathrm{hm}^{2}\end{array}$ & $\begin{array}{l}\text { Moth control } \\
\text { efficiency }(\%)\end{array}$ & $\begin{array}{l}\text { Infected hill } \\
\text { ratio (\%) }\end{array}$ & $\begin{array}{l}\text { Hill control } \\
\text { efficiency } \\
(\%)\end{array}$ & $\begin{array}{l}\text { Infected } \\
\text { plant ratio } \\
(\%)\end{array}$ & $\begin{array}{l}\text { Plants control } \\
\text { efficiency } \\
(\%)\end{array}$ & $\begin{array}{l}\text { Roll up } \\
\text { leaf ratio } \\
(\%)\end{array}$ & $\begin{array}{l}\text { Roll leaf contro } \\
\text { efficiency ( } \%)\end{array}$ \\
\hline $\begin{array}{l}\text { Light and } \\
\text { chemical control }\end{array}$ & $2,599.5$ & $95.0 \mathrm{a}$ & 11.7 & $88.3 \mathrm{a}$ & 1.3 & $98.6 \mathrm{a}$ & 0.50 & $98.7 \mathrm{a}$ \\
\hline $\begin{array}{l}\text { Light and no- chemical } \\
\text { control }\end{array}$ & $3,000.0$ & $94.2 \mathrm{a}$ & 16.7 & $83.3 \mathrm{a}$ & 5.2 & $94.2 \mathrm{a}$ & 1.98 & $95.0 \mathrm{a}$ \\
\hline $\begin{array}{l}\text { No-light and chemical } \\
\text { control }\end{array}$ & $13,275.0$ & $74.3 b$ & 64.0 & $36.0 \mathrm{~b}$ & 15.4 & $82.9 \mathrm{~b}$ & 5.54 & $85.9 \mathrm{~b}$ \\
\hline $\begin{array}{l}\text { No-light and no-chemical } \\
\text { control }\end{array}$ & $51,750.0$ & $0.00 \mathrm{c}$ & 100 & $0.00 \mathrm{c}$ & 90.1 & $0.00 \mathrm{c}$ & 39.5 & $0.00 \mathrm{c}$ \\
\hline
\end{tabular}

into a pest-collecting bag (Fig. 6a, b). The pest-killing lamps have been widely used in agriculture, forestry, vegetable and tobacco growing, warehouse storage, wine brewing, gardens, orchards, urban landscaping, and aquiculture in China. They can trap and kill a very large number of insects in a number of crops, including rice.

Rice insect pests control using pest-killing lamp was conducted in Guangdong, Guangxi (Liu et al. 2004; Luo et al. 2007; Deng and Li 2010; Wei and Chen 2003), Hunan (Zhou 2004; Huang et al. 2009b), Sichuan, Chongqing (Liu et al. 2004), Guizhou (Yang et al. 2004; Wang et al. 2011), Jiangxi, Anhui (Xia and Bao 2009; Xu et al. 2009), Jiangsu (Wang et al. 2010), Yunnan (Long et al. 2012), Hubei (Wang et al. 2006), and Zhejiang (Dong et al. 2011). More than 15 million hectares of rice crops used this technology for controlling insect pests between 2004 and 2011. Good control efficacy was gained and both the dosage and frequency of pesticides application were reduced. The average results showed that 4 orders, 16 families, and 41 species of rice insect pests were trapped and killed by pest-killing lamp. Among them, Naranga aenescens, Sogatella furcifera, Inazuna dorsalis, $N$. lugens, Empoasca flavescens, Inemadara oryzae, Chaphalocrocis medinalis, and T. incertulas were trapped and killed in large number, more than 500 were killed for each species, as shown in Table 6.

7.1 Installation of pest-killing lamp and control distance range

Pest-killing lamp should be installed at the center of target fields. The best height for the lamps was $155-170 \mathrm{~cm}$ from the ground to the middle of the lamp (or the bottom of the lamp was above $5-10 \mathrm{~cm}$ the height of the rice canopy). The control area of pest-killing lamp differed depending on different environments and crops. Generally, one pest-killing lamp can control 3.0-4.0 ha of rice crop.

7.2 Control efficiency of pest-killing lamp to different insect pests

The control efficiency of pest-killing lamp differed with rice insect pests. The control efficiency experiments were carried out in several different rice growing regions, e.g., Guangxi, Sichuan, Guizhou, Hunan, Hubei, and Jiangxi. The experimental treatments were as follows: (1) light and chemical control - pest-killing lamp was used and insecticide was applied twice; (2) light and no-chemical control-pest-killing lamp was used without using insecticides; (3) no-light and chemical control — no pest-killing lamp was used but insecticide was applied twice; (4) no-light and no-chemical control (as control) - no pest-killing lamp and insecticide was used. The area of each treatment was 3 ha and with no repeat, the lamp was installed in the center of the fields. The investigation was implemented every 10 days after the lamp installed. The results shown in Tables $7,8,9,10,11$, and 12 were averages from different places.

1. Control effect on rice leaf folder (Chaphalocrocis medina). The control efficiency to leaf folder of the treatments of (1) light and chemical control and (2) light and nochemical control were similar; however, the efficiency (3)

Table 8 Control efficiency of rice stem borer by pest-killing lamp

\begin{tabular}{|c|c|c|c|c|c|c|}
\hline Treatments & $\begin{array}{l}\text { Dead sheath } \\
\text { ratio }(\%)\end{array}$ & $\begin{array}{l}\text { Control efficiency } \\
\text { of dead sheath }(\%)\end{array}$ & $\begin{array}{l}\text { Dead heart } \\
\text { ratio }(\%)\end{array}$ & $\begin{array}{l}\text { Control efficiency } \\
\text { of dead heart }(\%)\end{array}$ & $\begin{array}{l}\text { White head } \\
\text { ratio }(\%)\end{array}$ & $\begin{array}{l}\text { Control efficiency } \\
\text { of white head (\%) }\end{array}$ \\
\hline Light and chemical control & $2.98 \pm 0.25 \mathrm{c}$ & $62.0 \mathrm{a}$ & $0.53 \pm 0.05 \mathrm{c}$ & $88.5 \mathrm{a}$ & $0.91 \pm 0.26 \mathrm{c}$ & $80.9 \mathrm{a}$ \\
\hline Light and no-chemical control & $5.57 \pm 0.33 b$ & $29.0 \mathrm{~b}$ & $1.83 \pm 0.11 b$ & $60.2 \mathrm{c}$ & $1.26 \pm 0.17 \mathrm{bc}$ & $73.6 b$ \\
\hline No-light and chemical control & $5.75 \pm 0.73 b$ & $26.7 b$ & $0.70 \pm 0.06 \mathrm{c}$ & $84.8 \mathrm{ab}$ & $1.44 \pm 0.18 b$ & $69.8 \mathrm{c}$ \\
\hline No-light and no-chemical control & $7.84 \pm 0.71 \mathrm{a}$ & $0.00 \mathrm{c}$ & $4.60 \pm 0.25 \mathrm{a}$ & $0.00 \mathrm{~d}$ & $4.77 \pm 0.20 \mathrm{a}$ & $0.00 \mathrm{~d}$ \\
\hline
\end{tabular}


Table 9 Control efficiency of plant hoppers by pest-killing lamp

\begin{tabular}{lccccc}
\hline \multirow{2}{*}{ Treatments } & \multicolumn{2}{c}{ Average of Guangxi, Sichuan and Guizhou } & & \multirow{2}{*}{ Average of Hunan, Hubei and Jiangxi } \\
\cline { 2 - 3 } \cline { 5 - 6 } & Insect pests amount of 100-hill & Control efficiency\% & & Insect pests amount of 100-hill & Control efficiency (\%) \\
\hline Light and chemical control & 97.9 & $92.4 \mathrm{a}$ & 225.4 & $93.4 \mathrm{a}$ \\
Light and no-chemical control & 335.0 & $73.9 \mathrm{c}$ & 684.0 & $79.6 \mathrm{c}$ \\
No-light and chemical control & 188.3 & $85.4 \mathrm{~b}$ & 350.5 & $89.7 \mathrm{~b}$ \\
No-light and no-chemical control & 1285.0 & $0.00 \mathrm{~d}$ & & $3,400.0$ & $0.00 \mathrm{~d}$ \\
\hline
\end{tabular}

no-light and chemical control was significantly lower than that of the former two treatments, as shown in Table 7.

2. Control effect on rice stem borers. Rice stem borers include the striped rice borer (C. suppressalis) and yellow rice borer (Scirpophaga incertulas). Stem borer caused different injured symptoms depending on the infected period of rice growing. The control efficiency to rice sheath dead of the treatment of (1) light and chemical was better than that of the treatments of (2) light and no-chemical control and (3) no-light and chemical control. Control efficiency to dead heart of the treatments of (1) light and chemical control, (3) no-light and chemical control were similar, but significantly higher than that of the treatments of (2) light and no-chemical control and (4) no-light and nochemical control. This suggests that pesticides application was quite important for effective control of dead heart caused by stem borer. The control efficiency to white head showed significantly different between treatments, from high to low was (1) light and chemical control, (2) light and no-chemical control, and (3) no-light and chemical control treatments, as shown in Table 8.

3. Control efficiency to plant hoppers. The investigation data were divided into two groups: group A includes Guangxi, Sichuan, and Guizhou provinces, and group B includes Hunan, Hubei, and Jiangxi provinces. Compared with the control (no-light and no-chemical control), the best control efficiency to plant hoppers was observed under the (1) light and chemical control treatment, the control efficiency of group A and group B was 92.4 and $93.4 \%$, respectively, followed by the treatment of (3) no-light and chemical control with 85.4 to $89.7 \%$. The treatment of (2) light and no-chemical control was relatively lower than the former. The results indicated that pesticides application without light was better than that of the treatment of light and nochemicals for controlling plant hoppers. See Table 9.

The amount of plant hoppers per 100-hill, the ratio of roll up leaf caused by leaf folder, and natural enemy of Cyrtorhinus lividipennis per 100-hill were surveyed every 10 days over 2 months (from 18 July to 16 September). Compare with no-light fields, the amount of plant hoppers of 100-hill in light fields were reduced by $52.6 \%$, and roll up leaves caused by leaf folder reduced by $71.4 \%$. The amount of natural enemy Cyrtorhinus lividipennis per 100-hill was reduced by $3.49 \%$ only, as shown in Table 10 .

The plant hoppers density of 100-hill of different distance places to the light were surveyed. The best range in relation to the control efficiency of plant hoppers was 0-20 m from the light, and then gradually decreased as the distance from the light increased. At the place of 101-120 m distance from the light, the

Table 10 Variation trend of insect pest amount in rice fields with light and with no-light

\begin{tabular}{|c|c|c|c|c|c|c|c|c|}
\hline \multirow{2}{*}{$\begin{array}{l}\text { Investigation date } \\
\text { (month/day) }\end{array}$} & \multicolumn{3}{|c|}{ Rice fields with no-light ${ }^{\mathrm{a}}$} & \multicolumn{5}{|c|}{ Rice fields with light ${ }^{\mathrm{a}}$} \\
\hline & $\begin{array}{l}\text { Plant hopper } \\
\text { amount/100 hill }\end{array}$ & $\begin{array}{l}\text { Ratio of roll } \\
\text { up leaves }(\%)\end{array}$ & $\begin{array}{l}\text { Cyrtorhinus } \\
\text { lividipennis / } \\
100 \text { hill }\end{array}$ & $\begin{array}{l}\text { Plant hopper } \\
\text { amount/100 hill }\end{array}$ & $\begin{array}{l}\text { Reduced } \\
\text { ratio of plant } \\
\text { hopper }(\%)^{b}\end{array}$ & $\begin{array}{l}\text { Ratio of roll } \\
\text { up leaves }(\%)\end{array}$ & $\begin{array}{l}\text { Reduced } \\
\text { ratio of leaf } \\
\text { folder }(\%)^{b}\end{array}$ & $\begin{array}{l}\text { Cyrtorhinus } \\
\text { lividipennis } \\
100 \text { hill }\end{array}$ \\
\hline $7 / 18$ & $88 \mathrm{~d}$ & $9.60 \mathrm{e}$ & $9 b$ & $40.3 \mathrm{e}$ & $54.3 \mathrm{c}$ & 2.3 & $76.0 \mathrm{a}$ & 8 \\
\hline $7 / 28$ & $102 \mathrm{c}$ & $15.6 \mathrm{c}$ & 6 & $47.3 \mathrm{~d}$ & $53.7 \mathrm{c}$ & 5.1 & $67.3 \mathrm{~d}$ & 6 \\
\hline $8 / 07$ & $155 \mathrm{a}$ & $19.2 b$ & 5 & $63.5 \mathrm{a}$ & $59.0 \mathrm{a}$ & 5.3 & $72.4 \mathrm{bc}$ & 3 \\
\hline $8 / 17$ & $147 b$ & $23.7 \mathrm{a}$ & 7 & $62.8 \mathrm{a}$ & $57.3 b$ & 6.2 & 73.7abc & 6 \\
\hline $8 / 27$ & $94 d$ & $14.5 \mathrm{c}$ & 8 & $58.8 \mathrm{~b}$ & $37.5 \mathrm{e}$ & 3.7 & $74.4 \mathrm{ab}$ & 9 \\
\hline $9 / 06$ & $102 \mathrm{c}$ & $8.30 \mathrm{e}$ & 10 & $52.0 \mathrm{c}$ & $49.0 \mathrm{~d}$ & 2.8 & $66.3 \mathrm{~d}$ & 19 \\
\hline $9 / 16$ & $88 \mathrm{~d}$ & $12.7 \mathrm{~d}$ & 15 & $37.5 f$ & $57.4 \mathrm{~b}$ & 3.7 & $71.2 \mathrm{c}$ & 7 \\
\hline Average & 110.9 & 14.8 & 8.6 & 51.7 & 52.6 & 4.2 & 71.4 & $8.3(3.49 \%)$ \\
\hline
\end{tabular}

${ }^{a}$ Five plots in light and three plots in no-light areas were investigated with three replications. Numbers in the table are averages

${ }^{\mathrm{b}}$ Compare with no light 
Table 11 Amounts of plant hoppers at different distances to the light

\begin{tabular}{llllllll}
\hline Investigation date (month/day) & No-light & \multicolumn{6}{l}{ Distance to the light (m) } \\
\cline { 3 - 8 } & & $0-20$ & $21-40$ & $41-60$ & $61-80$ & $81-100$ & $101-120$ \\
\hline $7 / 18$ & 88 & 21 & 30 & 35 & 50 & 53 & 75 \\
$7 / 28$ & 102 & 25 & 28 & 43 & 59 & 63 & 102 \\
$8 / 07$ & 155 & 20 & 42 & 59 & 73 & 76 & 148 \\
$8 / 17$ & 147 & 27 & 29 & 69 & 80 & 81 & 135 \\
$8 / 27$ & 94 & 18 & 40 & 71 & 83 & 83 & 100 \\
$9 / 06$ & 102 & 10 & 25 & 65 & 75 & 72 & 99 \\
$9 / 16$ & 88 & 9 & 22 & 35 & 49 & 57 & 75 \\
Total & 776 & 130 & 216 & 377 & 469 & 485 & 734 \\
Average & $110.9 \mathrm{a}^{\mathrm{a}}$ & $18.6 \mathrm{e}$ & $30.9 \mathrm{~d}$ & $53.9 \mathrm{c}$ & $67.0 \mathrm{~b}$ & $69.3 \mathrm{~b}$ & $104.9 \mathrm{a}$ \\
Control efficiency (\%) & $0.00 \mathrm{~g}^{\mathrm{a}}$ & $82.9 \mathrm{a}$ & $72.1 \mathrm{~b}$ & $51.4 \mathrm{c}$ & $39.6 \mathrm{~d}$ & $37.5 \mathrm{e}$ & $5.41 \mathrm{f}$ \\
\hline
\end{tabular}

light control efficiency in relation to plant hoppers was only $5.41 \%$ compared with no light fields, as shown in Table 11.

\subsection{Effect of pest-killing lamp on natural enemies}

Pest-killing lamp device partly has adverse impact on the natural enemies. The total numbers of insect pests and natural enemies in Guangxi, Sichuan, and Guizhou (group A) from 5 April to 20 August, and in Hunan, Hubei, and Jiangxi (group B) from 18 June to 20 August were investigated. The main natural enemies killed by pest-killing lamp were dragonfly (Odonata) and ladybeetle (Rodolia cardinalis). In group A, the amount of trapped and killed insect pests was 14,119, including 542 dragonflies and ladybeetles, thus leading to a ratio of beneficial insect vs harmful insect of 1:25. In group B, the total number of trapped and killed natural enemies was 147 and insect pests were 5,005, the ratio of beneficial insect vs insect pests was 1:34. The results indicated that the adverse impact on natural enemies of pest-killing lamp was far below the control effect on insect pests.

\subsection{Effects of pest-killing lamp on rice yield}

Rice yields of conventional rice and hybrid were tested in the field by using pest-killing lamp. Generally, the effect on hybrid rice yield of pest-killing lamp was better than that on conventional rice. Compared with (4) no-light and nochemical control treatment, the hybrid rice yield under (1) light and chemical control, (2) light and no-chemical control, and (3) no-light and chemical control treatments increased by $36.9,30.9$, and $33.5 \%$, respectively. For conventional rice, the yield increased by only $8.83,5.13$, and $3.66 \%$, respectively (Table 12).

\subsection{Benefit analysis of pest-killing lamp}

The costs (calculation of the double season rice, e.g., early rice and late rice according to the price in 2010) are as follows: one pest-killing lamp costs $350 ¥$ and the installation fee was $600 ¥$ (including concrete pole, electric wire, accessories, labor force, and other costs). Total cost of a pest-killing lamp amounts to $950 ¥$.

Generally, a pest-killing lamp can be used for 5 years, it means an annual cost of the lamp amounting to $190 ¥$. Electricity costs: the lamp was operated from $7.00 \mathrm{pm}$ to next day's $6.00 \mathrm{am}$, lamp began to open 21 March to the 20 August. The lamp opened $11 \mathrm{~h}$ every day for 153 days in total. The power of the lamp was $30 \mathrm{~W}$ and the cost was $0.8 ¥ /$ $\mathrm{kWh}$. The electricity charge for pest-killing lamp over a double rice season was $[(153 \times 11 \times 30) / 1,000] \times 0.8=63.1 ¥$. Hence, total costs of pest-killing lamp over a double rice season were $190+63.1=253.1 ¥$. Usually, a pest-killing lamp can control 4 ha of rice field, so the yearly cost of a hectare was $63.3 ¥$.

Generally, to achieve the same control efficiency to rice insect pests, the treatment of light and chemical control

Table 12 Effects on rice yield by pest-killing lamp

\begin{tabular}{lllll}
\hline Treatments & Conventional rice yield (kg/hectare) & Yield increased (\%) & Hybrid rice yield (kg/hectare) & Yield increased (\%) \\
\hline Light and chemical control & $5,743.5 \pm 3.11 \mathrm{a}$ & $8.83 \mathrm{a}$ & $8,607.3 \pm 1.95 \mathrm{a}$ & $36.9 \mathrm{a}$ \\
Light and no-chemical control & $5,548.1 \pm 2.11 \mathrm{~b}$ & $5.13 \mathrm{~b}$ & $8,231.6 \pm 1.29 \mathrm{c}$ & $30.9 \mathrm{c}$ \\
No-light and chemical control & $5,470.5 \pm 2.57 \mathrm{~b}$ & $3.66 \mathrm{c}$ & $8,394.0 \pm 1.78 \mathrm{~b}$ & $33.5 \mathrm{~b}$ \\
No-light and no-chemical control & $5,277.5 \pm 2.92 \mathrm{c}$ & $0.00 \mathrm{~d}$ & $6,287.6 \pm 1.70 \mathrm{~d}$ & $0.00 \mathrm{~d}$ \\
\hline
\end{tabular}


reduced insecticides application 1.5 times than that of no-light and chemical control treatment for a single rice season in a common year (that means the exception of the year that rice insect pests occurred particularly serious). This result in a three times reduction in chemical application in a year (double season rice). The costs of per hectare by increased three times of chemicals application in double season rice include $67.5 ¥$ of pesticides and $75.0 ¥$ of labor force. There are $270.0 ¥$ of chemicals and $300.0 ¥$ of labor force (totally $570 ¥$ ) saved for 4 ha. Deducting the cost of a pest-killing lamp (253.1 $¥$ for 4 ha), the cost of the treatment of light and chemical control was $316.9 ¥$ less than that of the no-light and chemical control treatment for 4 ha. That means one pest-killing lamp saved $79.2 ¥$ per hectare. The average yields of double season rice under light and chemical control treatment increased by $486 \mathrm{~kg}$ per hectare. The average rice price of early and late rice was $1.8 ¥$ per kilogram; thus, the increased income from yield was $3,499.2 ¥$ for 4 ha in a year. Total income for the light and chemical control treatment was increased by $3,816.1$ $¥(3,499.2+316.9)$ for 4 ha in a rice growing year (one pestkilling lamp increased $954.0 ¥$ per hectare).

In addition, as above mentioned, rice quality was improved, and environmental pollution was reduced due to the reduction both of the dosage and times of pesticides application. On the other hand, using of pest-killing lamp trapped and killed the insect pest species, the insect pest amount and main peak day occurrence can be used for forecasting the occurrence of insect pests (Table 4) and to guide the insect pests management.

Acknowledgments This work was supported by the following: (1) Span Plans of Agricultural Science and Technology (Contract number: 1999Kua-001, 2005Kua-001)," (2) National Special Project of Agricultural Industry (nyhyzx 3-16), (3) National Agricultural Science and Technology Support Program (2006BAD08A04), (4) National Project of "Science and Technology Promoting Action for Rice Comprehensive Productive Capacity," (5) Comprehensive Construction Project of Rural Energy of Ministry of Agriculture in 2005 "Rice yield increased technology integration and demonstration of biogas manures application," (6) Science and Technology Joint-operated Project of Zhejiang Provincial "Farmer and Rural Area and Five Departments" (SN200711), (7) State prop up plan "Studies, integration and demonstration of prevention and control technology for rice important pests" (2012BAD19B03).

\section{References}

Andow DA, Hidaka K (1989) Experimental natural history of sustainable agriculture: syndromes of production. Agric Ecosyst Environ 27: $447-462$

Asano H (2000) Effect of harvest time on protein composition (glutelin, prolamin, albumin) and amlose content in paddy rice cultivated by Aigamo duck farming system. Jpn Poult Sci 3:323-330

Bray F (1990) The rice economies, technology and development in Asian societies. Basil Blackwell, Oxford, 1986
Cao YJ (1999) Experiment of increasing rice yield by seed soaking with biogas fermentative liquid (slurry). China Biogas 4:34-35, in Chinese with English abstract

Castilla NP, Vera Cruz CM, Mew TW (2003) Using rice cultivar mixtures: a sustainable approach for managing diseases and increasing yield. Int Rice Res Notes 28:5-11

Chakraborty S, Newton AC (2011) Climate change, plant diseases and food security: an overview. Plant Pathol Spec Issue: Clim Chang Plant Dis 1:2-14

China National Rice Research Institute (CNRRI) (2011) State rice industrial technology developing centre. Report on China rice industrial development. Chinese Agricultural Publishing House, Beijing (in Chinese with English abstract)

Cox CM, Garrett KA, Bowden RL, Fritz AK, Dendy SP, Heer WF (2004) Cultivar mixtures for the simultaneous management of multiple diseases: tan spot and leaf rust of wheat. Phytopathology 94:961969

Dai DQ, Fan WY, Li JW, Kuang JR (2000) Experiment report of biogas fermentative liquid application on rice. China Biogas 2(34):36, in Chinese with English abstract

Deng MH, Li PQ (2010) An exploration to control rice insects by means of "Jiaduo" frequency insect-killing lamp and rice-duck production model. J Guangxi Agric 1(16-17):21, in Chinese

Deng QH, Pan XH (2008) Effects of rice-duck mutualism on diseases insect pests and weeds and economic benefits. Agric Sci Technol 1: 128-133, 138 (in Chinese with English abstract)

Deng QH, Pan XH, Wu JF, Shi QH (2007) Ecological effects and economic benefits of rice-duck farming. Chin J Ecol 4:582-586, in Chinese with English abstract

Dong YH, Zhang XY, Chen BZ, Xu PJ, Qian JR, He TH, Wang YP, Zhu CL, Wang HX, Zhang JP (2011) Control efficiency to the agricultural and forster pests of Jiaduo frequency insect-killing lamp in Zhejiang. Zhejiang Agric Sci 3:636-640, in Chinese

Feng XS, He HY, Jiang J, Yang XH, Liu X, Zhan JB, Huang FB, Yuan J (2007) Effects of different mixed inter-cropping pattern with different rice varieties on controlling rice blast. Guizhou Agric Sci 3:7374, in Chinese with English abstract

Gan XW, Luo SM (2008) Disease, insect pest and weed control of rice production in China by using biodiversity technology. Chin J Ecol 5: 853-857, in Chinese with English abstract

Gao GZ, Wang SW, Wang Q, Lü JF (2002) Pollution hazard and its management of residue pesticide. J Yan'an Univ (Nat Sci Ed) 1:5255, in Chinese with English abstract

Heong KL, Teng PS, Moody K (1995) Managing rice pests with less chemicals. GeoJournal 3:337-349

Hou LG, Zhao GC, Liu L, Guo XM, Sui PJ, Sun HJ (2009) Studies on controlling pest and weeds by integrated rice-duck farming technology. J Jilin Agric Sci 3:36-38, in Chinese with English abstract

Huang HZ, Huang XZ (2012) Technologies for fishes raising in paddy fields. Mod Agric Sci Technol (Zool Sci) 8:337, 343 (in Chinese)

Huang J, Qiao CL (2002) Application of the insect pests' detoxifying enzyme on the management of pesticides pollution and their mechanism. Agric Environ Prot 13:285-287, in Chinese with English abstract

Huang SW, Wang L, Chen HZ, Wang QY, Zhu DF (2009a) Effect of nitrogen dosage and fertilization approach on the occurrence of sheath blight disease in super hybrid rice (SHR). Acta Phytopathologica Sinica 1:104-109, in Chinese with English abstract

Huang ZN, Wen DH, Xu ZD, Zhang ZZ, Shi NZ, Peng MJ, Liu XX, Li ZL (2009b) The Control effects of rice-duck cultivation mode and insect killing lamp on three major rice pests. Hunan Agric Sci 11: 61-65, in Chinese

Jin SA, Yang YL, Gao SB, Li YQ, Jin CY, Wang J (2009) Effect of raising ducks in paddy field on yield and benefit of rice. North Rice 1:3537, in Chinese with English abstract 
Johnson MTJ, Lajeunesse MJ, Agrawal AA (2006) Additive and interactive effects of plant genotypic diversity on arthropod communities and plant fitness. Ecol Lett 9:24-34. doi:10.1111/j.1461-0248.2005. 00833.x

Kaut AHEE, Mason HE, Navabi A, O’Donovan JT, Spaner D (2008) Organic and conventional management of mixtures of wheat and spring cereals. Agron Sustainable Dev 28:363-371. doi:10.1051/ agro:2008017

Li KQ, Huang H, Ren ZM (2003) Technical demonstration and efficiency of rice-duck agroecosystem and frequoscillation pest-killing lamp in Hunan. China Rice 5:35-37, in Chinese

Li BT, Shi QH, Fang JH, Pan XH (2004) Techniques of diseases, insect pests and weeds control and their efficacy in bio-rational rice production. Chin J Appl Ecol 1:111-115, in Chinese with English abstract

Lin ZR, Jin ZZ (2002) Preliminary study on the control of rice pests by releasing ducks in rice field. Chin J Biol Control 2:94-95, in Chinese with English abstract

Liu CJ, Men WJ, Liu YJ, Zhang H (2002) Soil pollution by pesticides and polluted soil biorestoration. Agric Syst Sci Integr Study 4:295-297, in Chinese with English abstract

Liu EM, Zhu YY, Xiao FH, Luo M, Ye HZ (2003) Using genetic diversity of rice varieties for sustainable control of rice blast disease. Sci Agric Sin 2:164-168, in Chinese with English abstract

Liu XG, Tian J, Cai CY, Zhao L, Yuan YG (2004) Control of rice insect pests with Jiaduo trapping lamp. J Southwest Agric Univ (Nat Sci) 2:173-176, in Chinese with English abstract

Liu XY, Xiao TY, Huang H, Liu D, Zhong L, Wu LD (2006) The development rule of rice sheath blight in rice-duck-fish complex ecosystem. J Huazhong Agric Univ 2:138-141, in Chinese with English abstract

Long Y, Gao XH, Li HX, Tang ZM, Wu CL, Li PC, Tan YH, Li J (2012) Application and study of frequency-vibrancy pest-killing lamp during insect pest management in rice. Chin Agricul Sci Bull 15:216220, in Chinese with English abstract

Lü JP, Zhou JY (2004) Application of the biodiversity strategies in the control of rice blast by mixed cropping. China Plant Prot 2:8-10, in Chinese

Ludwig B, Geisseler D, Michel K, Joergensen RG, Schulz E, Merbach I, Raupp J, Rauber R, Hu K, Niu L, Liu X (2011) Review article: effects of fertilization and soil management on crop yields and carbon stabilization in soils. Agron Sustain Dev 31:361-372. doi: 10.1051/agro/ 2010030, INRA, EDP Sciences, 2010

Luo QB, Qiu RW, Zhang MX (2007) Studies on application technology of immigration insect pests by frequoscillation pest-killing lamp (FPKL) + duck releasing. China Plant Protection 20(supplement): 45-47, in Chinese

Mao JH, He M, He ZQ (1991) Effects of mixed plantings of resistant and susceptible varieties of rice on disease development. Acta Phytopathologica Sinica 2:155-160, in Chinese with English abstract

Miao YM, Stewart BA, Zhang FS (2011) Long-term experiments for sustainable nutrient management in China. A review. Agron Sustain Dev 31:397-414. doi:10.1051/agro/2010034, C INRA. EDP Science, 2011

Mundt CC (2002) Use of multiline cultivars and cultivar mixtures for disease management. Annu Rev Phytopathol 40:381-410. doi:10. 1146/annurev.phyto.40.011402.113723

Ngugi HK, King SB, Holt J, Julian AM (2001) Simultaneous temporal progress of sorghum anthracnose and leaf blight in crop mixtures with disparate patterns. Phytopathology 91:720-729

Oerke EC (2005) Crop losses to pests. J Agric Sci 144:31-43. doi:10. 1017/ S0021859605005708

Oerke EC, Dehne HW (2004) Safe guarding production-losses in major crops and the role of crop protection. Crop Prot 23:275-285

Oerke EC, Dehne HW, Schonbeck F, Weber A (1994) Crop production and crop protection-estimated losses in major food and cash crops. Elsevier, Amsterdam, 808 pp

Oka I (1988) Role of cultural techniques in rice IPM systems. In: Teng PS, Heong KL (eds) Pesticide management and integrated pest management. Consortium for International Crop Protection, 4321 Hartwick Rd., College Park, MD 20740 1988, pp. 83-94

Peng TS (2012) Technical measures for high yield of raising fishes in paddy fields. J Rural Anim-Breed Technol (Aquac) 8:42-43, in Chinese

Peng FM, Dai ZM, Manda M, Zhongxi LX, Yang HS, Zhang X, Zhu RJ, Zhao SM, Zhou XZ (2002) Studies and comprehensive evaluation of benefits of rice duck mutualistic eco-farming model in Yunnan Province. Chin Agric Sci Bull 3:34-36, in Chinese with English abstract

Pimentel D (1993) Reducing pesticide use through alternative agricultural practices: fungicides and herbicides. In: Altman J (ed) Pesticide interactions in crop production: beneficial and deleterious effects, 435-448. CRC, Boca Raton, pp 435-448

Popp J (2011) Cost-benefit analysis of crop protection measures. J Verbr Lebensm. 6(Suppl 1): S105-112. doi:10.1007/s00003-011-0677-4

Popp J, Pető K, Nagy J (2013) Pesticide productivity and food security. A review. Agron Sustain Dev 33: 243-255. doi: 10.1007/s13593 -0120105-x)

Potts MJ (1990) The influence of intercropping on pests and diseases of potato in warm climates with special reference to their control. Field Crops Res 25:133-144

Ratnadass A, Fernandes P, Avelino J, Habib R (2012) Plant species diversity for sustainable management of crop pests and diseases in agroecosystems: a review. Agron Sustain Dev 1:273-303. doi:10. 1007/s13593-011-0022-4

Ren JP, Guo XL, Wang JC, Xu RB, Han RT, Liu XM, Zhang JH, Wang SJ (2004) Technical research on mixture inter-planting of different rice varieties to control rice blast. J Jilin Agric Univ 4:414-415, 418 (in Chinese with English abstract)

Root RB (1973) Organization of a plant arthropod association in simple and diverse habitats: the fauna of collards (Brassica oleracea). Ecol Monogr 43:95-124

State Environmental Protection Administration (2001) Status, existing problem and suggestion of pesticide pollution in China. Environ Prot 6:23-24, in Chinese

Sun JZ, Zhu R (1990) Experiment of biogas manure application in paddy fields for preventing rice diseases and insect pests. China Biogas 4: 31-33, in Chinese with English abstract

Sun YJ, Bei ZM, Xie GH, Zhu GH (1999) Studies on the application of biogas fermentative liquid for controlling rice bacterial leaf blight and increasing rice yield. Plant Dr 3:30-31, in Chinese

Sun GC, Lu Y, Xiao SM (2002) Studies on the relation between the occurrence degree of yellow rice borer (Tryporyza incertulas) and rice sowing date. Plant Protect Technol Ext 2:8-9, in Chinese with English abstract

Tang Q (2007) DPS (C) Data processing system: experimental design, statistical analysis and data mining and the statistical soft ware. Science, Beijing

Technology Extension Main Station of Aquatic Product of Zhejiang Province (2012) Models and technology of paddy fields integration planting and breeding in Zhejiang Province. China Aquatic Prod 3: 47-48, in Chinese

Teetes GL, Anderson RM, Peterson GC (1994) Exploitation of sorghum non preference resistance to sorghum midge (Diptera: Cecidomyiidae) using mixed plantings of resistant and susceptible sorghum hybrids. J Econ Entomol 87:826-831

Thurston HD (1990) Plant disease management practices of traditional farmers. Plant Dis 74:96-102

Van Emden HF (1989) Pest control, 2nd edn. Edward Arnold, London, 117

Van Emden HF, Wratten SD, (1990) Tri-trophic interactions involving plants in the biological control of aphids. In: Peters DC, Webster JA, and Chlouber CS (eds). Aphid-plant interactions populations to molecules. Oklahoma State University, Stillwater, Oklahoma, pp:29-43

Vandermeer J, van Noordwijk M, Anderson J, Ong C, Perfecto I (1998) Global change and multispecies agroecosystems: concepts and issues. Agri Ecosyst Environ 67:1-22 
Vilich-Meller V (1992) Pseudocercosporella herpotrichoides, Fusarium spp. and Rhizoctonia cerealis stem rot in pure stands and interspecific mixtures of cereals. Crop Prot 11:45-50

Wang SL (2004) Rice, fishes, frogs and shrimps intergrowth, feeding the frogs with shrimps for increasing benefits. Handbook of BecomingRich by Fishery.14, 27 (in Chinese)

Wang H, Huang H (2002) Analysis of ecological and economic benefits of complex ecosystem in wetland paddy fields. Chin Agric Sci Bull 1:71-75, in Chinese with English abstract

Wang SN, Li WC (2007) Pesticides application status, effects and strategies in China. Modern Prev Med 20:3853-3855, in Chinese with English abstract

Wang GS, Long JH, Ran LJ (2003) Application study on biogas fermentative liquid (slurry) in rice seedling cultivation. Tillage and Cultivation 1(36):60, in Chinese

Wang QS, Huang PS, Zhen RH, Jing LM, Tang HB, Zhang CY (2004) Effect of rice-duck mutualism on nutrition ecology of paddy field and rice quality. Chin J Appl Ecol 4:639-645

Wang ZH, Yin XL, Rao QH, Dai H, Wang M, Li WB (2006) Studies on trapping effects of the lamps with frequency vibration on rice and vegetable insect pests. Hubei Agric Sci 4:460-462, in Chinese with English abstract

Wang XH, Wang LP, Zhu LQ, Bian XM (2010) Trapping and killing efficiency of frequency insect-killing lamp to rice insect pests in ricewheat rotation regions of the middle and lower reaches of Changjiang River. Jiangsu Agric Sci 4:117-119, in Chinese with English abstract

Wang ZW, Lu FL, Lei LY (2011) Control efficiency and benefits analysis of rice insect pests control by solar power frequency insect-killing lamp. Mod Agric Sci Technol (Plant Prot) 21:208, in Chinese

Wei W, Chen JC (2003) Preliminary study on the application of frequoscillation pest-killing lamp on rice. Guangxi Plant Protection 16(Supplementary issue):9-13, in Chinese

Wei SH, Qiang S, Ma B, Wei JG, Chen JW, Wu JQ, Xie TZ, Shen XK (2005) Control effects of rice duck farming and other weed management strategies on weed communities in paddy fields. Chin J Appl Ecol 6:1067-1071, in Chinese with English abstract

Wu MX (2011) A preliminary investigation of rice blast control via diversity cultivation of cultivars. J Mt Agric Biol 4:305-308, in Chinese with English abstract

Xia ZJ, Bao JS (2009) Experiments of the rice insect pests trapping and killing by using Jiaduo Frequency Insect-killing Lamp. Anhui Agric Sci Bull 20:85-144, in Chinese with English abstract

Xiong DZ, Liu SX, Li CY, Liu YP, Zeng WL (1996) Effects of combined application of organic-inorganic fertilizers on the nutrients of soil and the growth of tobacco. J Fujian Agric Univ 3:345-349, in Chinese with English abstract

Xu WH, Hu SK, Yao J, Zhang YM (2009) Studies on the efficiency of trapping and killing rice insect pests of frequency insect-killing lamp. Mod Agric Sci Technol (Plant Nurs) 15:143-145, in Chinese

Yang X, Hu XD, Wu BL, Tian Y (2004) The pest control by Jiaduo trapping lamps installation in the high quality rice planting areas. Guizhou Agric Sci 6:47-48, in Chinese

Yu SM, Jin QY (2006) Technology of rice duck farming system in paddy fields. China Agricultural Science and Technology, Beijing, in Chinese

Yu SM, Jin QY, Ouyang YN, Zhang QY, Xu DH, Shi SJ (2004a) The key technology and it's characteristic of pollution-free of rice-duck mutualism. Agric Environ Dev 6(8-9):15, in Chinese

Yu SM, Jin QY, OuYang YN, Xu DH (2004b) Efficiency of controlling weeds, insect pests and diseases by raising ducks in the paddy fields. Chin J Biol Control 2:99-102, in Chinese with English abstract

Yu SM, Ouyang YN, Zhang QY, Peng G, Xu DH, Jin QY (2005) Effects of rice duck farming system on Oryza sativa growth and its yield. Chin J Appl Ecol 7:1252-1256, in Chinese with English abstract

Yu SM, Jin QY, Zhu LF, Ouyang YN, Xu DH (2008a) Effect on rice yield and economic benefits of duck numbers in paddy fields. Zhejiang Agric Sci 1:68-71, in Chinese
Yu SM, Zhu LF, Ouyang YN, Xu DH, Jin QY (2008b) Effects of rice duck farming system on biotic populations in paddy field. Chin $\mathrm{J}$ Appl Ecol 4:807-812, in Chinese with English abstract

Zhang WD, Liu SQ, Lai JH, Xu QW, He CY (1996) The effects of anaerobic fermentation residue on prevention of diseases and insect pests for crops. China Biogas 1:5-9, in Chinese with English abstract

Zhang WD, Song HC, Wei XK (2001) Seed soaking technology with biogas fermentative liquid. Agric Technol 3:14-18, in Chinese

Zhang JE, Lu JX, Zhang GH, Luo SM (2002) Study on the function and benefit of rice-duck agro-ecosystem. Ecol Sci 1:6-10, in Chinese with English abstract

Zhang WD, Yin F, Li JC, Liu SQ, Chen YB, Xu L, Mao Y (2008) Influence of biogas fluid on the organic matter content in soil and its fertilization effect. Renew Energy Resour 6:45-47, in Chinese

Zhang JE, Xu RB, Chen X, Quan GM (2009a) Effects of duck activities on a weed community under a transplanted rice-duck farming system in southern China. Weed Biol Manag 3:250-257. doi:10. 1111/j.1445-6664.2009.00346.x

Zhang S, Chen QZ, Fang XW, Zou CH, Guo ML, Hong KM, Xu BY, Lü L, Chang XQ, Yang XL (2009b) Preliminary investigation of the relations between rice sowing date and the occurrence of diseases \& insect pests. Hubei Agric Sci 7:1644-1647, in Chinese with English abstract

Zhang S, Zhang QL, Chen XS, Jia ZB, Shangguan QH, Lü L, Chang XQ, Yang XL, Chen QZ (2009c) Effects of different cultivation model on the major rice diseases and insect pests occurrence. J Huazhong Agric Univ 4:426-430, in Chinese with English abstract

Zhao XQ, Liao HM (2006) Intercrop for rice blast management in Sichuan Province. Southwest China J Agric Sci 3:418-422, in Chinese with English abstract

Zhen RH, Wang QS, Shen XK, Zhang WJ, Bian XM, Huang PS (2004) Current status and technical prospect of rice-duck mutualistic ecofarming in China. Rural Eco-Environ 4:64-66, in Chinese

Zheng YH, Deng GB, Lu GM (1997) Economic benefits of rice-fishduck complex ecosystem: a preliminary study. Chin J Appl Ecol 4: 431-434, in Chinese with English abstract

Zhou SQ (2004) Studies on the rice insect pests control by frequency insectkilling lamp in large areas. China Plant Protection 11:36-38, in Chinese

Zhou YY, Zhang S (2011) Raising fishes in the paddy fields. New Agric 6:52-53, in Chinese

Zhu BQ (2000) Culturing Rana grylio for pest control in paddy field. Chin J Biol Control 4:186-187, in Chinese with English abstract

Zhu Y, Chen H, Fan JH, Wang Y, Li Y, Fan JX, Chen J, Fan JX, Yang S, Hu L, Leung H, Mew TW, Teng PS, Wang Z, Mundt CC (2000) Genetic diversity and disease control in rice. Nature 406:718-722

Zhu KM, Shen XK, Xie TZ, Dai WC, Chen LG, Gao JC, Wu JQ, Yang YJ, Chen WJ, Xu G (2001) Experiment preliminary report of rice duck mutualism technique. Anhui AgricSci 2:262-264, in Chinese with English abstract

Zhu YY, Chen HR, Fan JH, Wang YY, Li Y, Fan JX, Yang SS, Ma GL, Chen JB, Li ZS, Lu BR (2003) The use of rice variety diversity for rice blast control. Sci Agric Sin 5:521-527, in Chinese with English abstract

Zhu YY, Hei L, Chen HR, Wang YY, Tang KR, Zhao XQ, Zhou JY, Tu JH, Li YH, He XH, Zhou JH, Sun Y, Mew TW (2004a) Using resistance genes diversity for sustainable rice disease control. Sci Agric Sin 6:832-839, in Chinese with English abstract

Zhu YY, Sun Y, Wang YY, Li Y, He YQ, He XH, Mundt CC, Tom WM, Hei L (2004b) Genetic analysis of rice varietal diversity for rice blast control. Acta Genet Sin 7:707-716, in Chinese with English abstract

Zhu JL, Cao KR, Sun XL, Chen Y (2011a) Effect on the occurrence of rice black-streaked dwarf virus of rice varieties and seeding day. China Plant Prot 12:19-22, in Chinese

Zhu JL, Zhu ZR, Feng JX, Cai XT, Zhong XM, Cheng JA (2011b) Effect of sowing/transplanting time on occurrence of main locallyoverwintering insect pests and diseases. Acta Agric Zhejiangensis 2:329-334, in Chinese 